\title{
Quantifying Energy and Mass Fluxes Controlling Godthåbsfjord Freshwater Input in a 5-km Simulation (1991-2012)*,+
}

\author{
P. L. LANGEN, ${ }^{\#}$ R. H. Mottram, ${ }^{\#, @ ~ J . ~ H . ~ C h r i s t e n s e n, ~}$, @ F. BoberG,, ,@

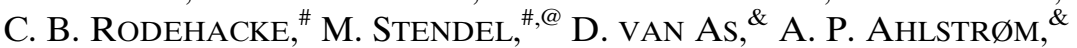 \\ J. Mortensen, ${ }^{@}$ S. RYSGAARD $,{ }^{\circledR}, * *+++$ D. PETERSEN, ${ }^{\# \#}$ K. H. SVENDSEN, ${ }^{\# \#}$ \\ G. AðALGEIRSDÓTTIR, ${ }^{@}$ AND J. CAPPELEN" \\ \# Danish Meteorological Institute, Copenhagen, Denmark \\ @ Greenland Climate Research Centre, Greenland Institute of Natural Resources, Nuuk, Greenland \\ \& GEUS, Geological Survey of Denmark and Greenland, Copenhagen, Denmark \\ ** Center for Earth Observation Science, CHR Faculty of Environment, Earth, and Resources, \\ University of Manitoba, Winnipeg, Manitoba, Canada \\ ${ }^{++}$Arctic Research Centre, Aarhus University, Aarhus, Denmark \\ \#\# Asiaq, Greenland Survey, Nuuk, Greenland \\ ${ }^{\circledR}$ Institute of Earth Sciences, University of Iceland, Reykjavik, Iceland
}

(Manuscript received 8 April 2014, in final form 27 January 2015)

\begin{abstract}
Freshwater runoff to fjords with marine-terminating glaciers along the Greenland Ice Sheet margin has an impact on fjord circulation and potentially ice sheet mass balance through increasing heat transport to the glacier front. Here, the authors use the high-resolution $(5.5 \mathrm{~km})$ HIRHAM5 regional climate model, allowing high detail in topography and surface types, to estimate freshwater input to Godthåbsfjord in southwest Greenland. Model output is compared to hydrometeorological observations and, while simulated daily variability in temperature and downwelling radiation shows high correlation with observations (typically $>0.9$ ), there are biases that impact the results. In particular, overestimated albedo leads to underestimation of melt and runoff at low elevations.

In the model simulation (1991-2012), the ice sheet experiences increasing energy input from the surface turbulent heat flux (up to elevations of $2000 \mathrm{~m}$ ) and shortwave radiation (at all elevations). Southerly wind anomalies and declining cloudiness due to an increase in atmospheric pressure over north Greenland contribute to increased summer melt. This results in declining surface mass balance (SMB), increasing surface runoff, and upward shift of the equilibrium line altitude.

SMB is reconstructed back to 1890 though regression between simulated SMB and observed temperature and precipitation, with added uncertainty in the period 1890-1952 because of possible inhomogeneity in the precipitation record. SMB as low as in recent years appears to have occurred before, most notably around 1930, 1950, and 1960. While previous low SMBs were mainly caused by low accumulation, those around 1930 and in the 2000 s are mainly due to warming.
\end{abstract}

* Supplemental information related to this paper is available at the Journals Online website: http://dx.doi.org/10.1175/JCLI-D14-00271.s1.

${ }^{+}$Nordic Centre of Excellence Stability and Variations of Arctic Land Ice Contribution Number 39.

Corresponding author address: Peter L. Langen, Climate and Arctic Research, Danish Meteorological Institute, Lyngbyvej 100, DK-2100 Copenhagen, Denmark.

E-mail: pla@dmi.dk

\section{Introduction}

The Greenland Ice Sheet is currently experiencing increasing annual-mean near-surface air temperatures, linked to regular persistent negative phases of the North Atlantic Oscillation (NAO), causing high melt rates in summer due to relatively clear skies, warm air masses, and low wintertime precipitation rates (Box et al. 2012; Fettweis et al. 2013b). Recurring negative summer NAO since 2007 has thus led to a series of years with low 
surface mass balance (SMB) for the ice sheet compared to preceding decades, culminating in a new melt record where nearly $100 \%$ of the ice sheet surface experienced melt in July 2012 (Nghiem et al. 2012; Tedesco et al. 2013; Hanna et al. 2014; Häkkinen et al. 2014).

Analyses of data from the Gravity Recovery and Climate Experiment (GRACE) satellites have shown that the total mass balance since the launch of the satellites (March 2002) has been predominantly negative, although numbers vary depending on the time period studied and the glacial isostatic rebound model used to correct the data (e.g., Wouters et al. 2008; Velicogna 2009; Velicogna and Wahr 2013). Although it is difficult to formally attribute the recent mass loss to global climate change, an Arctic warming amplified relative to the global mean is a very robust result in projections of future climate (Christensen et al. 2014). Much research is therefore directed at determining the mass changes due to surface and dynamic processes (e.g., van den Broeke et al. 2009; Ettema et al. 2009; Rignot et al. 2011; Shepherd et al. 2012; Barletta et al. 2013; Vaughan et al. 2014; Aschwanden et al. 2013; Vernon et al. 2013) in a collective effort to improve our understanding of the system and give reliable estimates for the ice sheet contribution to future sea level rise (e.g., Gillet-Chaulet et al. 2012; Rae et al. 2012; Church et al. 2014; Fettweis et al. 2013a; Goelzer et al. 2013; Aðalgeirsdóttir et al. 2014). Studies with regional climate models [RCMs; e.g., Modèle Atmosphérique Régional (MAR; Fettweis 2007), HIRHAM5 (Lucas-Picher et al. 2012), RACMO2 (van Angelen et al. 2013)] are an integral part of this effort.

A number of studies focus on individual basins of the ice sheet to understand how SMB varies interannually (e.g., van de Wal et al. 2005, 2012; Mernild et al. 2011; van As et al. 2014). Regional-scale studies of the underlying processes and spatial details in projected future change are important both as building blocks toward a full-system understanding and to local communities depending on the runoff from rainfall and ice melt as an important source of drinking water and for producing hydropower.

Here, we focus on Godthåbsfjord $\left(64^{\circ} \mathrm{N}\right)$, a sill fjord with tidewater outlet glaciers in southwest Greenland. The aim of the study is to analyze recent changes in the individual energy and freshwater components that drive the SMB in the area by taking advantage of an unprecedented horizontal resolution in the HIRHAM5 simulation (Christensen et al. 2006) and to provide estimates for the freshwater input to the fjord (excluding frontal and subglacial ablation).

Mernild and Liston (2012) found that, over the last half-century, southwest Greenland has experienced the largest increases in runoff, and there is ample evidence that runoff affects fjord circulation (Motyka et al. 2003;
Rignot et al. 2010; Straneo et al. 2011; Mortensen et al. 2011). Subglacial freshwater discharge, which entrains (nutrient rich) deeper water masses, initiates a circulation that may impact heat exchange between the fjord and the shelf region (Mortensen et al. 2013, 2014). Increased runoff may therefore result in a positive feedback on the frontal ablation of the ice sheet. These processes are important in Godthåbsfjord and, with relatively good coverage of oceanographic and land- and glacier-based surface observations, it is an obvious testing ground for improving the understanding of mass balance and runoff, also because it encompasses a large fraction of Greenland's population.

The complex orographic setting in the Godthåbsfjord region with steep topography, complex land-sea distribution and multiple narrow outlet glaciers (Fig. 1) is a challenge to models, however. In a recent study by van As et al. (2014), where the RCMs RACMO2 and MARv3.2 were run at $11-$ and $25-\mathrm{km}$ resolution, respectively, the model output was therefore regridded to a higher resolution $(250 \mathrm{~m})$ and extrapolated to account for unresolved-glacier points. In this study, we use the HIRHAM5 for Greenland at a resolution of about $5.5 \mathrm{~km}$ (Lucas-Picher et al. 2012). Analyses by Ettema et al. (2009) and Lucas-Picher et al. (2012) suggest that such high resolution is necessary to resolve the coastal topography impacting variables such as near-surface air temperature and precipitation. Figure $1 \mathrm{~b}$ illustrates how the model's glacier and sea grid cells (white and blue rasters) begin to resolve the narrow outlet glaciers and fjord arms, avoiding the steps of regridding and extrapolation. Comparisons of simulated surface temperature, winds, albedo, etc., with observations, as shown in detail in the online supplemental material, are thus based on direct model output (except for lapse rate corrections of temperatures due to model-data differences in elevation). The diagnosed changes in energy fluxes, SMB components, and fjord runoff are likewise based on direct model output. Using these fields, we can study details of the spatial pattern of the changes and evaluate equilibrium line changes against satellite observations.

In section 2, we describe the model and the experimental design. Section 3 provides a model evaluation against observations, while section 4 presents the results of the experiment. Discussion and conclusions are given in sections 5 and 6 , respectively.

\section{Model description and simulations}

The RCM HIRHAM5 is a hybrid between the dry dynamical core of the HIRLAM numerical weather forecasting model (Eerola 2006) and physics schemes derived from the ECHAM5 general circulation model (Roeckner et al. 2003). The details of the configuration 


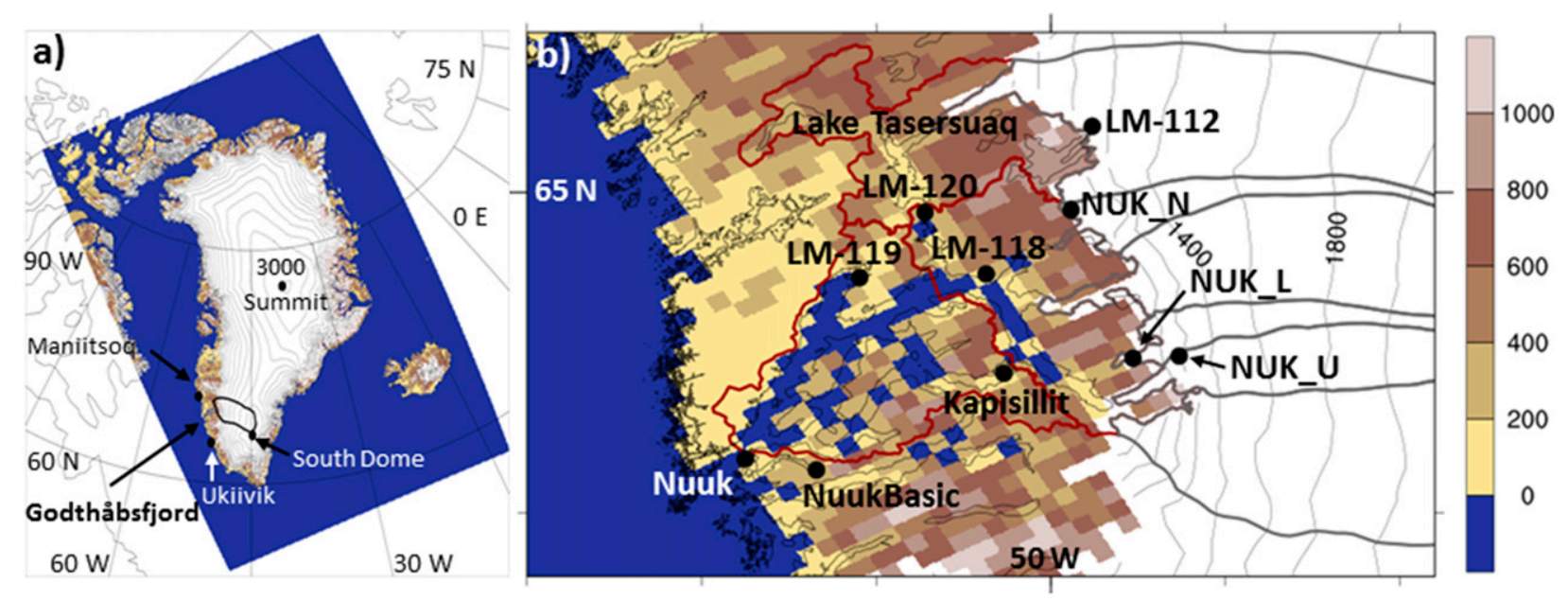

FIG. 1. (a) The model domain showing sea (blue), land (brown), and glacier (white) grid cells. Surface elevation is shown in land points by shading $(\mathrm{m})$ and on the ice sheet by contours (3000-m contour is marked and interval is $200 \mathrm{~m}$ ). The black line in southern Greenland outlines the ice sheet drainage basin for Godthåbsfjord. (b) Close-up view of the Godthåbsfjord region. Weather stations used for model evaluation are shown with dots [stations outside this region are shown in (a)]. Also shown are the drainage basin outlines: Red lines delineate tundra basins and gray lines show the ice sheet basins. At the ice-tundra boundary, the latter also illustrate the true ice sheet margin for comparison with the model-resolved margin (white grid cells). Dots mark the observation sites used in the study (Table S1).

are described by Christensen et al. (2006) and the model and its predecessors have been employed in various studies of Arctic and Greenland permafrost and ice sheet SMB (Box and Rinke 2003; Mernild et al. 2011; Daanen et al. 2011; Rinke et al. 2012; Rae et al. 2012).

\section{a. Surface scheme updates}

Compared to the original HIRHAM5 (Christensen et al. 2006) that used unchanged ECHAM5 physics (Roeckner et al. 2003), the surface scheme used in this study has been modified over glaciers and ice sheets to include a dynamic snow/ice scheme. This has been done by modifying the original five-layer surface scheme of ECHAM5 to explicitly calculate melting of snow and bare ice and to resolve retention and refreezing of liquid water throughout the column.

Accumulation of snow is accounted for such that snow water equivalent is updated with snowfall, melt, and sublimation at each time step. The surface temperature is updated in each time step using radiative and turbulent surface energy fluxes combined with diffusive and advective heat exchange with subsurface layers. Whenever the surface reaches a temperature above $0^{\circ} \mathrm{C}$, it is reset to $0^{\circ} \mathrm{C}$ and the corresponding excess heat supplies latent heat for melting in the surface layer.

The five layers together have a water equivalent (w.eq.) depth of $10 \mathrm{~m}$, and each layer consists of mass fractions of snow, ice, and liquid water. Currently, the layers employ constant densities for snow $\left(330 \mathrm{~kg} \mathrm{~m}^{-3}\right)$, ice $\left(917 \mathrm{~kg} \mathrm{~m}^{-3}\right)$, and liquid water $\left(1000 \mathrm{~kg} \mathrm{~m}^{-3}\right)$. As surface melt and rainfall occur, retention is calculated in each of the five layers by letting liquid water in excess of $4 \%$ of the snow mass in the layer percolate to the layer below. With a snow density of $330 \mathrm{~kg} \mathrm{~m}^{-3}, 4 \%$ per snow mass corresponds to a pore space volume fraction of about 2\% (Coléou and Lesaffre 1998), the same value as used in the Simulation of Glacier Surface Mass balance and Related Sub-surface processes (SOMARS) snow model in RACMO2 (Reijmer et al. 2012). A layer with a fractional ice mass greater than $85 \%$ is impermeable and the excess liquid runs off $(85 \%$ corresponds to the fraction that yields a layer-mean density of $830 \mathrm{~kg} \mathrm{~m}^{-3}$, the pore close-off density; Cuffey and Paterson 2010). Likewise, excess liquid water from the lowermost layer runs off. When water runs off, it is removed from the grid cell immediately; horizontal flow or routing of meltwater from grid cell to grid cell is not calculated.

The cold content in each layer (i.e., the heat capacity and difference in temperature from the freezing point) is used to freeze liquid water, transferring mass to the ice fraction and raising the temperature of the layer accordingly to conserve energy. When the layer reaches the freezing point, the cold content has been depleted, and no further refreezing takes place until the layer is cooled again by diffusion or advection. The bottom of the lowest model layer is assumed to exchange mass and energy with an infinite layer of ice with a temperature of $-10^{\circ} \mathrm{C}$ (a typical deep firn temperature in the absence of latent heating due to refreezing in a west Greenland section; Humphrey et al. 2012). The lower boundary depth of $10 \mathrm{~m}$ w.eq. below the surface is set in the design of the original ECHAM5 surface scheme (Roeckner 
et al. 2003) and will in most cases adequately include the seasonal snow layer.

In the updated model, a more sophisticated snow/ice albedo scheme was included. For the albedo of snow on land, Roeckner et al. (2003) employ a temperature dependent ramping between a warm snow and a cold snow albedo. Their values have been modified to a fresh dry snow albedo of 0.85 (e.g., van de Wal and Oerlemans 1994; Cuffey and Paterson 2010) when snow is colder than $-5^{\circ} \mathrm{C}$ and a linear decrease to 0.65 [old snow value in van de Wal and Oerlemans (1994)] as snow temperature increases from $-5^{\circ}$ to $0^{\circ} \mathrm{C}$ (Roeckner et al. 2003). The albedo of bare clean ice varies in the literature between 0.30 and 0.46 (Cuffey and Paterson 2010); our model uses 0.40 , which is the minimum value employed in MARv3.2 (van As et al. 2014). Finally, we use an exponential transition between the snow and bare ice albedos based on the snow depth [as in Oerlemans and Knap (1998), with $e$-folding depth of $3.2 \mathrm{~cm}$ for snow].

$\mathrm{SMB}$ is computed from the precipitation $P$ minus the mass flux of evaporation/sublimation $E$ and runoff of liquid water RO,

$$
\mathrm{SMB}=(P-E)-\mathrm{RO} .
$$

Precipitation is the sum of rain $R$ and snowfall $S$, and the runoff equals the liquid water from melt $M$ and rain minus the refreezing and retention RF. Therefore,

$\mathrm{SMB}=(S+R-E)-(M+R-\mathrm{RF})=(S-E)-M+\mathrm{RF}$.

The SMB is therefore given by the solid accumulation minus melt plus refreezing, where "solid accumulation" is the term we will use throughout for snowfall minus sublimation. Sublimation of blowing snow is not taken into account.

\section{b. Experimental design}

In this study, the HIRHAM5 is run at $\sim 5.5-\mathrm{km}$ resolution $\left(0.05^{\circ} \times 0.05^{\circ}\right.$ on a rotated pole grid; Lucas-Picher et al. 2012). In this configuration, the model employs 31 hybrid atmospheric levels in the vertical with a top pressure of $10 \mathrm{hPa}$ and a time step of $90 \mathrm{~s}$. The model is configured in an all-Greenland domain illustrated in Fig. 1. Surface elevation of the ice sheet is specified from the Bamber et al. (2001) database, which has high accuracy (within a few meters) in the flat ice sheet interior. However, errors up to several hundred meters tend to occur near the coast and a more accurate elevation model (Howat et al. 2014) will be employed in future HIRHAM5 Greenland configurations. At the lateral boundaries, the model is forced at $6-\mathrm{h}$ intervals with horizontal wind vectors, temperature, and specific humidity at all atmospheric levels and with surface pressure. These forcing fields are taken from the ERAInterim dataset (Dee et al. 2011). At the lower boundary, sea surface temperatures and sea ice concentrations derived from the same dataset are prescribed. Narrow fjords are not resolved by the ERA-Interim dataset, and values from open ocean points are bilinearly extrapolated inward to provide boundary data for the model's fjord grid points. In land points, surface temperatures are calculated as part of the model climate. The model was run for 1989-2012, but only the period 1991-2012 is used in the analysis. The first $2 \mathrm{yr}$ are regarded as spinup to allow land surface temperatures and soil moisture to equilibrate.

In this study, the snow/ice surface scheme described in section $2 \mathrm{a}$ is run offline, forced every $6 \mathrm{~h}$ by surface fluxes of energy (radiative and turbulent) and mass (snow, rain, evaporation, and sublimation) from a HIRHAM5 experiment with an earlier implementation of bare ice albedo and refreezing. Because of the large computational cost of the high-resolution HIRHAM5 RCM, this offline configuration is a fast and flexible option, allowing a thorough spinup of the subsurface. In the following, reported values of albedo, upward longwave radiation, subsurface heat exchange, melt, refreezing, runoff, and SMB are derived from this offline run. A disadvantage of this configuration is that feedbacks between surface conditions (e.g., albedo) and the atmospheric circulation are neglected. However, the snow albedo parameterization is unchanged from our original HIRHAM5 experiment; since surface temperatures are typically near the freezing point in the presence of bare ice, changes in bare ice albedo are unlikely to play a major role for upward longwave radiation and turbulent fluxes. These fluxes provide the feedback to the atmosphere, so, while the surface scheme updates are important for melting, refreezing, and mass budgets, the effects of neglected atmospheric feedbacks are likely small. Nevertheless, the updated surface scheme is implemented as an integrated part of HIRHAM5 for future applications.

The surface scheme was initialized with first-guess temperatures and snow in the three upper layers and ice in the lower two. The model was then integrated for $30 \mathrm{yr}$, repeating year 1990 forcing. During this spinup, the major adjustments occurred during the first decade, after which the residual tendencies were orders of magnitude smaller than the interannual variability during the 1989-2012 simulation. At the end of spinup, temperatures and snow, ice, and liquid water fractions in all subsurface layers had converged, as had SMB, melting, refreezing, and runoff. The final state after the 
$30 \mathrm{yr}$ was used as initial condition for the time dependent 1989-2012 integration.

Figure 1a shows the model domain and surface topography. Grid cell rasters in Fig. 1b illustrate the high resolution of the model and the level of orographical detail. This shows how narrow fjord arms $(\sim 5 \mathrm{~km})$ and outlet glaciers are resolved at this resolution. To determine which grid cells contribute to freshwater runoff into Godthåbsfjord, we use hydrological drainage basin delineations from van As et al. (2014), thereby allowing direct comparison with their results. Watersheds in the tundra (red lines in Fig. 1b) were delineated using the ASTER digital elevation model (Hvidegaard et al. 2012) and aerial photography. Over the ice sheet, delineations (gray lines) were derived from the 2005/06 Radarsat surface velocity map (Joughin et al. 2010) and it is implicitly assumed that flow of ice and englacial water is controlled by both surface and bottom topography (for details, see van As et al. 2014). Furthermore, this allows us to calculate the total mass balance of separate glaciers taking into account frontal ablation. While only the lower parts of the ice sheet are shown in Fig. 1b, the entire drainage basin is outlined in Fig. 1a.

Currently, the model does not include horizontal flow and routing of freshwater, and basin delineations as the one used here are necessary to determine the runoff into a specific fjord. Water routing delays in the supraglacial, englacial, subglacial, and proglacial system are not taken into account (except in Fig. 3c, which gives a visual daily time-scale comparison) since they are not important here where focus is on seasonal or longer time scales.

\section{Model evaluation against observations}

Lucas-Picher et al. (2012) evaluated the HIRHAM5 at $0.25^{\circ}$ and $0.05^{\circ}$ resolutions against weather station and ice core data with focus on long-term annual and seasonal means over Greenland. In the $0.05^{\circ}$ experiment, simulated 2-m temperatures agree with observations within $2 \mathrm{~K}$ over Greenland in summer (multistation correlation 0.98), while winter temperatures (correlation 0.97) are somewhat lower than observed in the southwest (down to $5 \mathrm{~K}$ ) and higher at higher elevations of the ice sheet (up to $5 \mathrm{~K}$ ). Precipitation biases are both positive and negative across Greenland but, on the ice sheet, the $0.05^{\circ}$ experiment showed a spatial correlation of 0.96 and biases in the south generally smaller than $10 \%$ compared to ice corederived accumulation rates (Andersen et al. 2006; Banta and McConnell 2007; Bales et al. 2009). The small temperature biases and the high resolution were concluded to render the HIRHAM5 simulations suitable for driving ice sheet models (Aschwanden et al. 2013; Aðalgeirsdóttir et al. 2014) and deliver the required quality for climate studies. In the online supplemental material accompanying this study, we give a detailed comparison between model output and meteorological observations at the stations in or near the Godthåbsfjord region marked in Fig. 1 and assess the degree to which local-scale and daily variability is captured in the model simulation. The findings of that analysis are summarized in the following subsection after which summer ablation and basin-scale runoff are compared to observations.

\section{a. Meteorological variables}

Figures $2 \mathrm{a}-\mathrm{c}$ show an example comparison between simulated and observed daily variability in surface air temperature and downwelling longwave (LW) and downwelling shortwave (SW) radiation at the on-ice Programme for Monitoring of the Greenland Ice Sheet (PROMICE) NUK_L site during 2008. Synoptic-scale variations in these variables appear to agree in magnitude and timing at this low-elevation site $(560 \mathrm{~m} ; 552 \mathrm{~m}$ in the model). Figures $2 \mathrm{~d}-\mathrm{f}$ show scatter diagrams of $3 \mathrm{yr}$ of observations (20 August 2007-19 August 2010; statistical details are given in Table S2). Temperature shows a cold bias, particularly in winter, and a negative bias in the downwelling $\mathrm{LW}$ radiation in the upper parts of both the cold and warm season ranges points to an underestimation of cloud cover during overcast conditions. Departures in downwelling SW fluxes are more frequently too high than too low, consistent with an underestimation of cloud cover at this site.

In general, the comparison in the online supplemental material between surface observations at 15 weather stations (Steffen et al. 1996; Steffen and Box 2001; Ahlstrøm et al. 2008; Iversen and Thorsøe 2009; Cappelen 2013; van As et al. 2013) and HIRHAM5 output shows that daily, synoptic-type variability in the area is captured by the simulation. Correlation between observed and simulated 2-m temperatures is high both on and off the ice sheet (0.84-0.98), and the range of variability is well captured (slope of a least squares fit is $0.88-1.1$ ). Temperatures on the ice sheet generally display a cold bias in the model (up to $2.7 \mathrm{~K}$ ) as do winter temperatures off the ice sheet (up to $5.5 \mathrm{~K}$ ). Off-ice summer temperature biases are positive near the ice sheet (up to $2.1 \mathrm{~K}$ ) and negative closer to sea (up to $1.7 \mathrm{~K}$ ). Summer half-year [April-September (AMJJAS)] and annual means of observed and simulated temperatures are highly correlated $(>0.95)$ both on and off the ice sheet.

Modeled precipitation is compared to off-ice observations and there is a large positive bias $(\sim 200 \%)$ near the ice sheet and smaller or negative biases closer to sea $(+70 \%$ to $-20 \%)$. While undercatch in precipitation gauges is a known problem that is most pronounced for solid precipitation (Yang et al. 1999), observed 
Near-surface air temperature
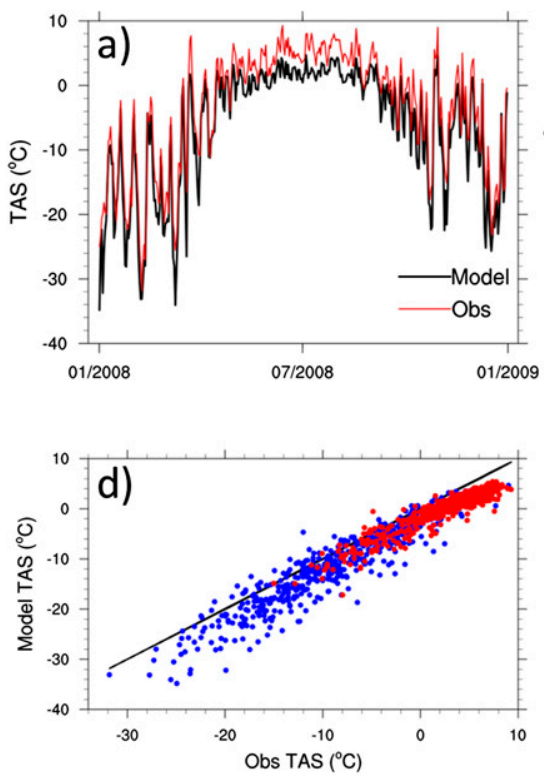

Downwelling LW

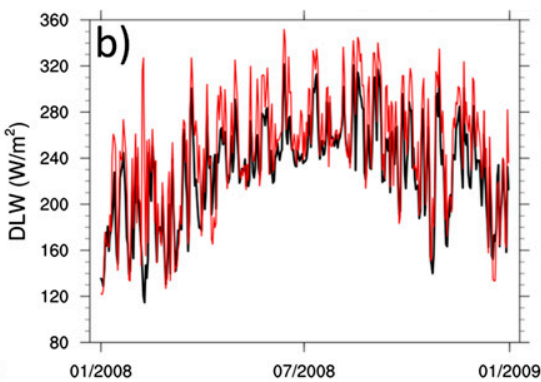

Downwelling SW

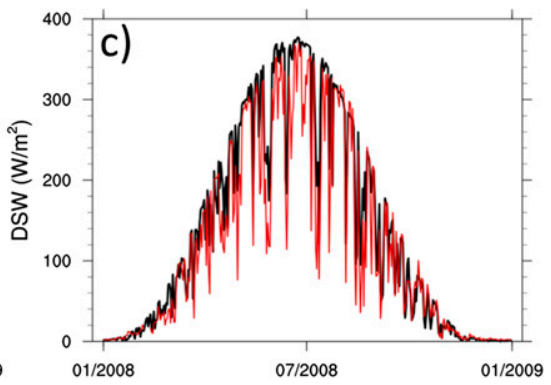

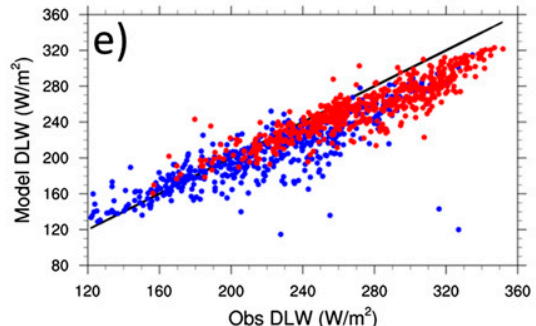

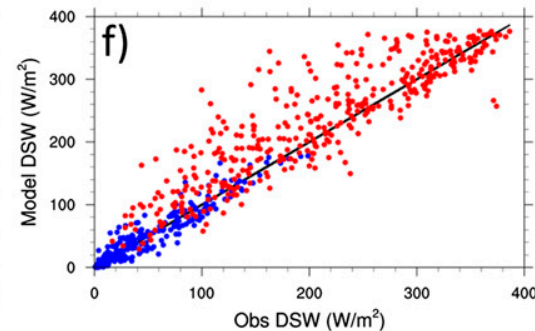

FIG. 2. Daily averaged observations and model output at the PROMICE NUK_L site. Shown are subsets of the full series showing (a) nearsurface air temperature and downwelling (b) LW and (c) SW radiation. (d)-(f) Scatterplots for 3 yr of data (20 Aug 2007-19 Aug 2010) of (a)-(c). Blue dots are winter half-year [October-March (ONDJFM)], red dots are summer (AMJJAS), and black lines denote a 1:1 relationship.

precipitation is typically only corrected by $40 \%-60 \%$ at west Greenland sites (e.g., Allerup et al. 2000; Mernild et al. 2015). It appears that the topographic enhancement of precipitation near the margin is too effective in HIRHAM5 [as found by Herrera et al. (2010), noting also that lee side precipitation appears to be underestimated], and this is also likely to apply for accumulation on the lower parts of the ice sheet. AMJJAS and annual simulated and observed precipitation generally correlate with values ranging from 0.6 to 0.9 . While the off-ice precipitation comparisons indicate that HIRHAM5 is too wet, the ice core comparison by Lucas-Picher et al. (2012) showed biases in the region below $10 \%$ (spatial correlation of 0.96 ). Hence, we have reason to trust our simulation for on-ice precipitation but to note that precipitation near the margin likely is overestimated.

Consistent with too low atmospheric temperatures, the downwelling $\mathrm{LW}$ on the ice sheet is underestimated with biases ranging between 10 and $20 \mathrm{~W} \mathrm{~m}^{-2}$. For downwelling SW radiation, the summer half-year values show spatially varying biases. At the PROMICE sites, they range roughly from +20 to $-10 \mathrm{Wm}^{-2}$. At higher elevations, modeled AMJJAS-mean albedos are in agreement with observations with mean biases ranging from 0.05 to -0.02 . At the two lowest-elevation PROMICE sites (NUK_L and NUK_N), the minimum model albedo of 0.4 is too high to simulate the lowest observed albedos. This results in positive AMJJAS-mean biases of about 0.1, while the snowfall and temperature control on surface albedo variability give correlations of $0.55-0.73$.

Finally, modeled daily surface wind speeds show small biases (up to $1.7 \mathrm{~m} \mathrm{~s}^{-1}$ ) and high correlation with observations (above 0.8, except at NUK_L, which is in a narrow valley). Wind direction variability is represented in Fig. S1. The 5.5-km resolution employed here, traditionally referred to as "gray zone," sometimes causes problems because the convective parameterizations are not designed for it. The fidelity of modeled surface winds indicates, however, that this concern is not relevant in this Arctic application where convective events rarely are important.

\section{b. Melt and freshwater runoff}

At the PROMICE stations NUK_L (560 m; $552 \mathrm{~m}$ in the model), NUK_N (930 $\mathrm{m} ; 886 \mathrm{~m}$ in the model), and NUK_U (1140 m; $1177 \mathrm{~m}$ in the model), we compare records of ablation season surface height changes (in meters w.eq., estimated using a pressure transducer assembly, which measures ablation, not accumulation; Fausto et al. 2012) with simulated height changes from HIRHAM5. These are calculated as snowfall minus the sum of sublimation, evaporation, and melt; the retention/refreezing which enters into the full SMB is discounted here since it occurs below the surface and is not seen in the height change. Figure 3a shows the comparison between height changes. The simulated changes at NUK_L, NUK_N, and NUK_U are underestimated by $34 \%$ (5-yr average), 

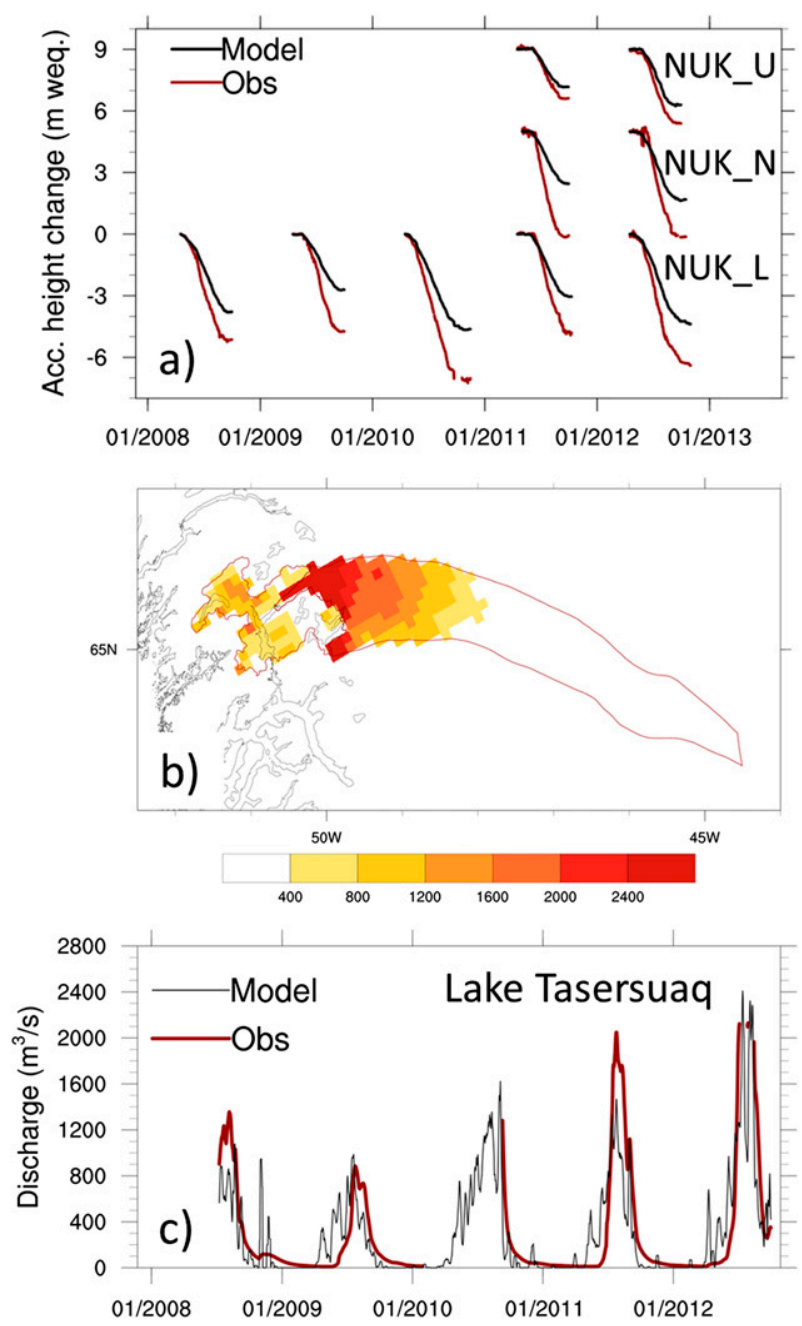

FIG. 3. (a) Ablation season height changes (meters w.eq.) at the PROMICE NUK_L, NUK_N, and NUK_U sites as observed (red) and simulated (black). The starting points of the curves have been adjusted vertically so they start each spring at 0,5 , and $9 \mathrm{~m}$, respectively, for the three sites. (b) Annual average model runoff from the Lake Tasersuaq drainage basin for the period 2007-12 (in mm w. eq. $\mathrm{yr}^{-1}$ ). (c) Daily discharge from Lake Tasersuaq as observed by Linking Ice Sheet Thinning and Changing Climate (FreshLink) and London Mining (red) and as derived from the modeled runoff (black). The modeled discharge is calculated as the Lake Tasersuaq drainage basin sum and in this plot is delayed and smoothed by averaging over the preceding 1-7 days.

$43 \%$ (2-yr average), and $24 \%$ (2-yr average), respectively. The overestimated summer albedo combined with the radiation biases and the underestimated atmospheric temperatures evidently resulted in reduced melt energy particularly at the lowest elevations, as is also seen in other models (van As et al. 2014).

These pointwise evaluations are augmented by a largescale comparison of area totals between HIRHAM5 modeled runoff and measured discharge at Lake Tasersuaq.
The ice sheet drainage basin for this lake is the northernmost of the basins shown in Fig. 1b (also outlined in Fig. $3 b$ ) and drains $27 \%$ of the whole catchment area. The water level in the lake has been monitored by Asiaq (Greenland Survey) since 2008 with two pressure transducers. These measurements are converted into discharge values by a relation based on 15 manual measurements of discharge. The mean annual discharge derived from these measurements has an uncertainty of 5\% (at 95\% confidence level) as estimated by Asiaq [in accordance with International Organization for Standardization (1998)].

Figure $3 \mathrm{~b}$ shows the simulated 2007-12 mean annual runoff (in $\mathrm{mm} \mathrm{yr}^{-1}$ ) over the region draining into Lake Tasersuaq (both glacier and tundra points). Simulated daily runoff produces a highly variable signal, not taking into account delays in the supraglacial, englacial, or subglacial system or the proglacial complex of lakes feeding into Lake Tasersuaq. For the illustration in Fig. $3 c$ only, the daily integrated model runoff was therefore delayed and smoothed by averaging over the preceding 1-7 days (black curve in Fig. 3c). Averaging over periods with observations, the integrated model runoff is about $10 \%$ lower than observed. As seen in Fig. 3b, a substantial proportion of the simulated lake runoff originates from the tundra area of the catchment. In fact, the spikes during spring and fall come from the tundra because of snowmelt and rainfall. As noted by van As et al. (2014), much of the spring melt from the tundra evaporates from smaller lakes in the catchment, penetrates to the groundwater, or contributes to a $\sim 7$-m rise in the Lake Tasersuaq water level in spring.

In the model, only $4 \%$ of the Godthåbsfjord ice sheet drainage basin is below $1000 \mathrm{~m}$, but about a third of the total ice sheet runoff is generated in this area. As suggested by the pressure transducer results in Fig. 3a, the simulated meltwater production from this area is substantially lower than in reality. Therefore, the underestimated discharge from Lake Tasersuaq is likely due to the high model albedo, radiation bias, and cold bias in these low-elevation parts of the ice sheet.

\section{Results}

In this section, we analyze the simulated SMB and freshwater runoff to the fjord, focusing on surface freshwater and energy fluxes, then on equilibrium line altitude (ELA) changes, and finally on the freshwater input in the fjord system. As discussed in section 1, Greenland has experienced increasing temperatures over the simulation period and, in the analyses, we focus on trends and differences between the first and last half of the simulation: period 1 is defined as 1991-2001 and period 2 is defined as 2002-12. 

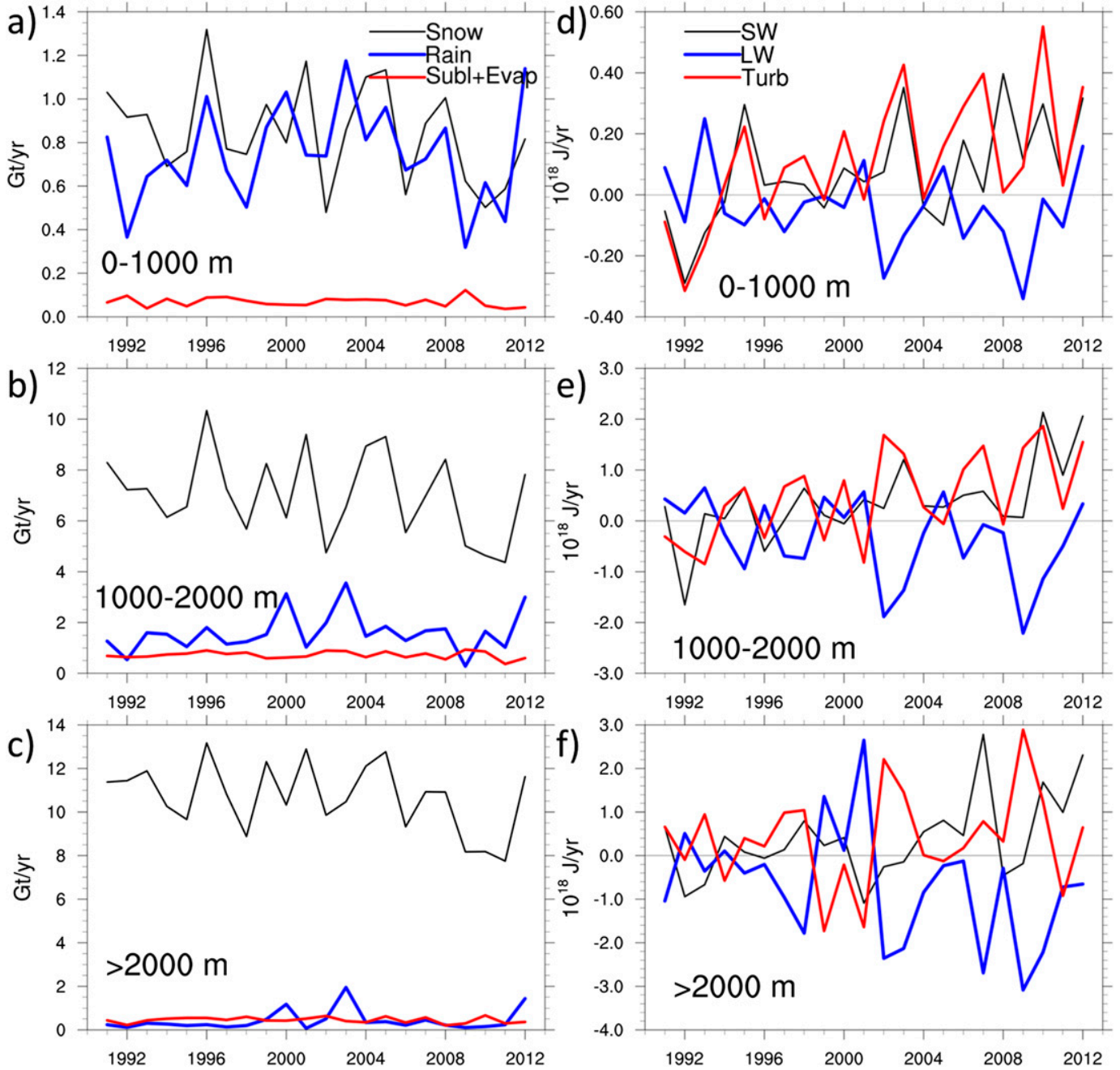

FIG. 4. (a)-(c) Simulated total annual snowfall (black), rainfall (blue), and sublimation plus evaporation (red) from surface-elevation intervals 0-1000 m, 1000-2000 m, and $2000 \mathrm{~m}$ upward on the ice sheet. (d)-(f) As in (a)-(c), but for energy flux anomalies: net SW (black), net LW (blue), and turbulent (red). Anomalies are relative to the period 1 (1991-2001) average (Table 1) and are displayed as positive downward. Note the different scales on the vertical axes. The areas covered by the three height intervals are 1630,12020 , and $26620 \mathrm{~km}^{2}$, respectively.

\section{a. Surface input of mass and energy}

Figures $4 \mathrm{a}-\mathrm{c}$ shows the annual mass fluxes through snowfall, rainfall and evaporation (plus sublimation) for the Godthåbsfjord ice sheet drainage basin in three surface-elevation intervals: $0-1000 \mathrm{~m} \mathrm{(4 \%} \mathrm{of} \mathrm{the} \mathrm{basin}$ area), $1000-2000 \mathrm{~m}$ (30\% of the basin area), and $2000 \mathrm{~m}$ and upward ( $66 \%$ of the basin area). None of the curves shown in Figs. $4 \mathrm{a}-\mathrm{c}$ has significant trends at the $95 \%$ level (see appendix for details on statistical significances). The annual snowfall rates at the middle and upper intervals appear to be decreasing, but large interannual variability renders the trends insignificant. Similarly, the rain-to-snow ratio (rainfall/snowfall) appears to increase through the simulation period as atmospheric temperatures increase, but in none of the intervals is the change statistically significant. Surface evaporation and sublimation is small compared to snowfall, and its variability is in absolute terms unimportant for the variability of the mass budget.

Net SW radiation and turbulent (latent plus sensible) heat fluxes generally contribute positively to the surface energy budget and are approximately balanced by the net outgoing LW flux. The fluxes do not balance identically; in fact, it is their residual in addition to subsurface heat exchange that provides the energy for surface melting. Figures $4 d-f$ shows the area average annual-mean surface energy fluxes during the simulation for the three surface-elevation intervals. Since variations are generally small compared to the mean 
TABLE 1. Annual averages over periods 1 and 2 and their difference $(\Delta=$ period $2-$ period 1$)$ integrated over the entire Godthåbsfjord drainage basin of the ice sheet (total), over the area with negative SMB in period 1 (SMB $<0 ; 16 \%$ of the drainage basin), and over the area with positive SMB in period 1 (SMB $>0 ; 84 \%$ of the drainage basin). Bold indicates changes that are significant at the $95 \%$ level.

\begin{tabular}{|c|c|c|c|c|c|c|c|c|c|}
\hline & \multicolumn{3}{|c|}{ Total } & \multicolumn{3}{|c|}{$\mathrm{SMB}<0$} & \multicolumn{3}{|c|}{$\mathrm{SMB}>0$} \\
\hline & 1991-2001 & $2002-12$ & $\Delta$ & 1991-2001 & $2002-12$ & $\Delta$ & 1991-2001 & 2002-12 & $\Delta$ \\
\hline \multicolumn{10}{|l|}{ Mass $\left(\mathrm{Gt} \mathrm{yr}^{-1}\right)$} \\
\hline SMB & 7.3 & 1.0 & -6.3 & -5.9 & -9.1 & -3.2 & 13.2 & 10.1 & -3.1 \\
\hline Solid accumulation & 18.3 & 16.3 & -2.0 & 3.1 & 2.6 & -0.5 & 15.2 & 13.7 & -1.5 \\
\hline Melt & 20.4 & 26.3 & 5.9 & 11.3 & 14.0 & 2.7 & 9.1 & 12.3 & 3.2 \\
\hline Refreezing & 9.4 & 11.0 & 1.6 & 2.3 & 2.3 & 0.0 & 7.1 & 8.7 & 1.6 \\
\hline Rain & 2.5 & 3.1 & 0.6 & 1.4 & 1.5 & 0.2 & 1.1 & 1.6 & 0.4 \\
\hline Runoff & 13.5 & 18.4 & 4.9 & 10.4 & 13.3 & 2.9 & 3.1 & 5.2 & 2.1 \\
\hline \multicolumn{10}{|l|}{ Energy $\left(\mathrm{W} \mathrm{m}^{-2}\right)$} \\
\hline Net SW & 26.7 & 28.0 & 1.3 & 36.2 & 39.0 & 2.8 & 24.9 & 26.0 & 1.0 \\
\hline Net LW & -45.5 & -47.2 & -1.7 & -49.1 & -50.8 & -1.7 & -44.9 & -46.6 & -1.7 \\
\hline Turbulent & 22.2 & 23.8 & 1.6 & 28.8 & 32.2 & 3.5 & 20.9 & 22.1 & 1.2 \\
\hline Subsurface flux & 2.0 & 2.4 & 0.4 & 2.8 & 2.8 & 0.0 & 1.9 & 2.3 & 0.4 \\
\hline
\end{tabular}

values, the fluxes are shown as anomalies relative to their period 1 averages (Table 1 ). In all three intervals, the turbulent and LW flux anomalies anticorrelate. Interannual variability in turbulent heat flux is dominated by sensible heat flux variations (not shown) and, in years with increased horizontal atmospheric heat advection, an increased downward sensible heat flux warms the surface. This leads to increased upward LW fluxes and provides a mechanism for the anticorrelation.

Net SW has a significant upward trend (at 95\%) in all three surface-elevation intervals, while turbulent fluxes have a significant upward trend at the low and middle intervals only. There are no significant linear trends in the net LW fluxes at any of the intervals. While downwelling SW fluxes have positive trends in all intervals, the melt-albedo feedback plays a decisive role in determining the net SW trends especially in the low and middle intervals.

\section{b. SMB and equilibrium line altitude changes}

As defined in section $2 \mathrm{a}$, the SMB is derived from three components: solid accumulation (snowfall minus sublimation and evaporation), melt, and refreezing [Eq. (2)]. Annual totals of the three components over the simulation are shown in Fig. 5a. For the whole period 1991-2012, the average simulated contributions are $17.3 \pm 3.4 \mathrm{Gt} \mathrm{yr}^{-1}$ from solid accumulation, $-23.4 \pm$ $6.9 \mathrm{Gtyr}^{-1}$ from melt, and $10.2 \pm 2.7 \mathrm{Gt} \mathrm{yr}^{-1}$ from refreezing, resulting in an SMB of $4.1 \pm 6.3 \mathrm{Gt} \mathrm{yr}^{-1}$ for the Godthåbsfjord drainage basin (Fig. 5b). Here, and in the following, " \pm " gives the standard deviation.

Table 1 provides an overview of annual-mean freshwater and energy fluxes on the ice sheet. The columns labeled "total" show averages for period 1 and period 2 along with their difference for the total Godthåbsfjord drainage basin. In period 1, melting amounts to $20.4 \pm 4.4 \mathrm{Gtyr}^{-1}$ (see also horizontal lines in Fig. 5a), while in period 2 this has increased to
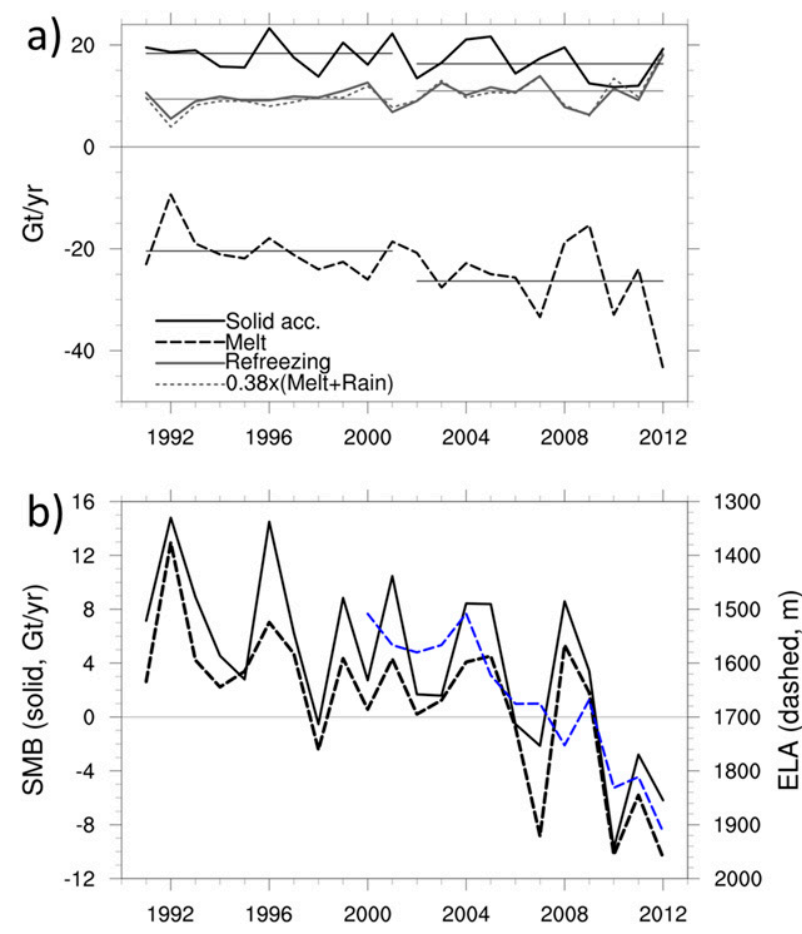

FIG. 5. (a) Annual sums of simulated ice sheet SMB components [Eq. (2)] for the entire Godthåbsfjord drainage basin: solid accumulation (snow minus sublimation and evaporation; black), melt (black dashed; counts negatively in the SMB), and refreezing (gray). Thin horizontal lines indicate period means. The gray dotted line shows an approximation to refreezing calculated as $0.38 \times$ (melt + rain). (b) Annual SMB totals (solid; left axis) and annual ELA in the model (black dashed; right axis; notice reversed scale) and as derived from MODIS images along the PROMICE NUK section (blue dashed; right axis). 
$26.3 \pm 7.8 \mathrm{Gt} \mathrm{yr}^{-1}$. This increase in melt of $5.9 \mathrm{Gt} \mathrm{yr}^{-1}$ (29\%) is statistically significant at the $95 \%$ level in spite of the change being comparable to the standard deviation (appendix). The solid accumulation rate decreases $2.0 \mathrm{Gt} \mathrm{yr}^{-1}$ and the refreezing rate increases $1.6 \mathrm{Gt} \mathrm{yr}^{-1}$, but none of these changes are significant. The result is a significant SMB change from $7.3 \pm$ $4.8 \mathrm{Gt} \mathrm{yr}^{-1}$ to $1.0 \pm 6.1 \mathrm{Gtyr}^{-1}$. This decrease of $6.3 \mathrm{Gt} \mathrm{yr}^{-1}$ is chiefly due to increased melting.

As illustrated in Fig. 4, the (insignificant) change in solid accumulation is due to changes in snowfall rather than sublimation and evaporation. The $5.9 \mathrm{Gt}$ increase in annual melt is due to significant positive changes in net SW and turbulent fluxes and an offsetting negative change in net LW flux (Table 1). Interestingly, despite the insignificant trends in net LW flux at the three surfaceelevation intervals in Fig. 4, the total net LW flux changes significantly between the periods (Table 1). As net SW and turbulent fluxes increase, the surface warms up and increases the upward LW flux. In this manner, the net LW flux acts as a negative feedback offsetting part of the extra energy input. Taken over the total area, the LW flux offsets about half of the extra input added by SW, turbulent, and subsurface heat exchange.

The annual-mean SMB for the two periods is shown in Figs. 6a,b and their difference is shown in in Fig. 6c. Thick black solid lines in Figs. 6a,b show the period average ELA (repeated as solid and dashed lines in Fig. 6c). An upward migration of the ELA is evident. By averaging the altitude over grid cells with $|\mathrm{SMB}|<100 \mathrm{~mm} \mathrm{yr}^{-1}$, the ELA is estimated to change significantly (at 95\%) from $1600 \mathrm{~m}$ above mean sea level in period 1 to $1743 \mathrm{~m}$ in period 2. The annual ELA over the simulation is shown with the black dashed line in Fig. 5b (notice the reversed scale). The SMB and ELA are anticorrelated $(-0.94)$ and, for each $100 \mathrm{~m}$ the ELA migrates upward, the drainage basin integrated SMB decreases by approximately $4 \mathrm{Gt} \mathrm{yr}^{-1}$.

Optical remote sensing with the Moderate Resolution Imaging Spectroradiometer (MODIS) instrument on the NASA Terra satellite has been used to determine the snow line position just prior to the first winter snow (Benson and Box 2008). This was done in $0.1^{\circ}$ intervals of latitude along both the west and east coast of Greenland. Choosing the 66th percentile value (in meters above mean sea level) in each latitude band produces the best match along the $\mathrm{K}$ transect with observed ELAs by van de Wal et al. (2012). The resulting MODIS-derived ELA is shown as a period 2 average in Fig. 6b (blue dashed line). In the southern part of the catchment, agreement between model- and MODISderived ELAs is within about $0-200 \mathrm{~m}$. In the central part, where the model displays a separate region of
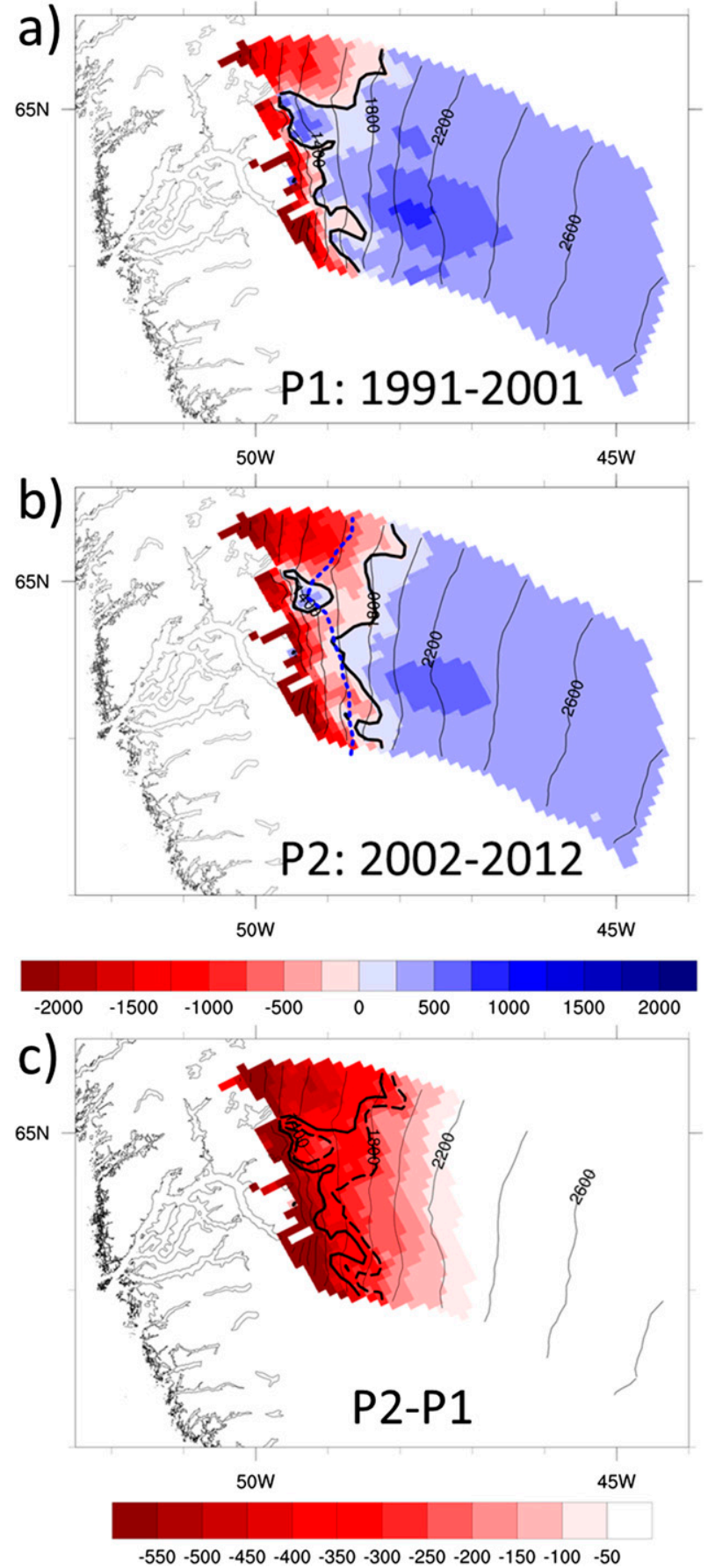

FIG. 6. Simulated mean annual SMB $\left(\mathrm{mm} \mathrm{yr}^{-1}\right)$ over the study area for (a) period 1 and (b) period 2. Thick black lines indicate the equilibrium line and in (b) the dashed blue line shows the MODISderived equilibrium line averaged over period 2. (c) Difference period $2-$ period $1\left(\mathrm{~mm} \mathrm{yr}^{-1}\right)$. Thick solid and dashed lines show modeled period 1 and 2 equilibrium lines, respectively. Thin contours show the surface elevation $(\mathrm{m})$. 
positive SMBs close to the margin, the MODIS-derived ELA agrees with this position. In the northernmost part, the model-derived ELA is $200-300 \mathrm{~m}$ higher than the MODIS-derived one. J. E. Box (2014, personal communication) extracted a 2000-12 time series of annual ELAs along the PROMICE NUK transect, and this series is plotted alongside the drainage basin mean model ELA in Fig. 5b. In spite of some differences, giving a correlation of only 0.7 , the two series have upward slopes that are statistically indistinguishable from each other (at 95\%).

In period 1 , the area of the ablation zone (where SMB $<0$ ) is $16 \%$ of the entire Godthåbsfjord drainage basin. In period 2 this area has increased to $23 \%$. The difference map in Fig. $6 \mathrm{c}$ shows that the largest decreases in SMB occur in the low-elevation areas, although considerable SMB decrease occurs above the period 1 ELA. Table 1 gives the freshwater and energy fluxes from the period 1 ablation zone $(\mathrm{SMB}<0)$ and accumulation zone (SMB $>0$ ), respectively. Of the $6.3 \mathrm{Gt} \mathrm{yr}^{-1}$ decrease in SMB, $3.2 \mathrm{Gt} \mathrm{yr}^{-1}$ originate from the $16 \%$ of the area covered by the period 1 ablation zone and the remaining $3.1 \mathrm{Gt} \mathrm{yr}^{-1}$ originate from the former accumulation zone.

In the period 1 ablation zone, solid accumulation and refreezing changes are practically negligible and the 3.2 $\mathrm{Gt} \mathrm{yr}^{-1}$ SMB change originates predominantly from increased melt. In spite of the increased melt, refreezing is unchanged since the shallow snow layer on top of the ice is already using all the cold content for refreezing in period 1 . The increased melt is caused by increases in net SW and turbulent fluxes of 2.8 and $3.5 \mathrm{~W} \mathrm{~m}^{-2}$, respectively, and a decrease of $1.7 \mathrm{~W} \mathrm{~m}^{-2}$ in the net LW flux. In the large area covered by the period 1 accumulation zone (83\%), a decrease in solid accumulation, and an increase in refreezing of about 1.5 $\mathrm{Gt} \mathrm{yr}^{-1}$ balance. The $3.1 \mathrm{Gt} \mathrm{yr}^{-1}$ decrease in SMB is thus due to the increase in melt. In the accumulation zone where the surface temperature less frequently reaches the melting point, upward LW radiation can balance the increased incoming energy fluxes. Consequently, the net increase in melt energy is only $0.9 \mathrm{~W} \mathrm{~m}^{-2}$ (compared to $4.6 \mathrm{~W} \mathrm{~m}^{-2}$ in the ablation zone).

\section{c. Fjord freshwater input}

Figure $7 \mathrm{a}$ shows the simulated contributions to freshwater input to the fjord from precipitation minus evaporation directly over the fjord (red) and runoff from land points (black) and ice sheet points (blue) for period 1 (solid) and period 2 (dashed). The inputs are shown as cumulated mass over each month of the year. In spring, the meltwater from snow on tundra dominates the input.
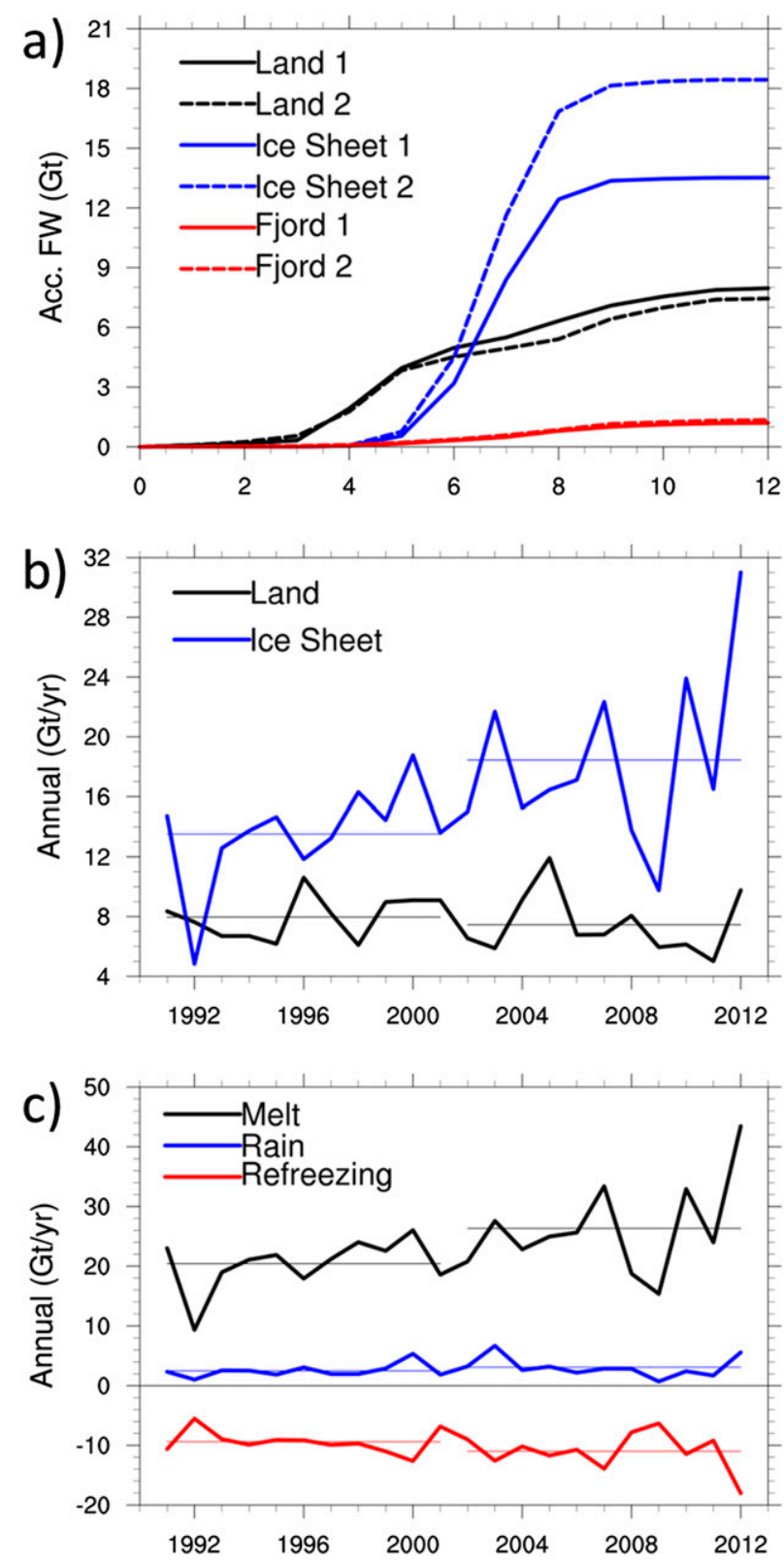

FIG. 7. (a) Simulated monthly cumulated freshwater input to Godthåbsfjord averaged over periods 1 (solid) and 2 (dashed) from runoff from land (black), runoff from the ice sheet (blue), and precipitation minus evaporation directly over the fjord (red). (b) Annual totals of simulated freshwater runoff to the fjord integrated over land and ice sheet points. (c) Annual sums of the components of ice sheet runoff: melt (black), rain (blue), and refreezing (red). Thin horizontal lines indicate period means.

When the ice sheet melt season commences, the freshwater input is dominated by the ice sheet runoff. On average over the entire 1991-2012 period, our model provides $25.0 \pm 5.9 \mathrm{Gt}$ of freshwater to the fjord (excluding iceberg calving and basal and submarine melt from the glaciers in contact with the fjord), with contributions of 
$16.0 \pm 5.3 \mathrm{Gt}$ from ice sheet surface runoff, $7.7 \pm 1.8 \mathrm{Gt}$ from land points, and $1.3 \pm 0.4 \mathrm{Gt}$ from direct precipitation minus evaporation over the sea points.

Annual land and ice sheet runoff contributions during the simulation are shown in Fig. 7b. There is no significant trend in the land contribution with averages of $8.0 \pm$ 1.4 and $7.5 \pm 2.1 \mathrm{Gt} \mathrm{yr}^{-1}$ in periods 1 and 2 , respectively. The ice sheet runoff, however, increases significantly by $36 \%$ from $13.5 \pm 3.4 \mathrm{Gt} \mathrm{yr}^{-1}$ to $18.4 \pm 5.8 \mathrm{Gt} \mathrm{yr}^{-1}$ between the two periods. In Fig. 7c, the three components of the ice sheet runoff (melt, rainfall, and refreezing) are shown. In absolute terms, the rain increases only slightly (and insignificantly) from 2.5 to $3.1 \mathrm{Gt} \mathrm{yr}^{-1}$, while the melt, as discussed above, increases significantly from 20.4 to $26.3 \mathrm{Gt} \mathrm{yr}^{-1}$. Refreezing increases (insignificantly) by $1.6 \mathrm{Gt} \mathrm{yr}^{-1}$. The melt contribution to fjord hydrology thus dominates over rain in both the absolute values and the change.

As seen in Table 1 , the period 1 ablation zone $(\mathrm{SMB}<0)$ and accumulation zone $(\mathrm{SMB}>0)$ contribute with comparable amounts (2.9 and $2.1 \mathrm{Gt} \mathrm{yr}^{-1}$, respectively) to the change in runoff. This increase in runoff corresponds to $28 \%$ and $68 \%$ in the ablation and accumulation zone, respectively, and the upward migration of the ELA has a dramatic effect on the runoff from the previous accumulation zone. The contributions to runoff from the ice sheet are shown in Fig. 8a for 400-m surface-elevation intervals. The magnitude of these contributions is characterized by large per-area runoff in the low-elevation, small-area bins and small per-area runoff in the highelevation, large-area bins. The largest runoff occurs in the interval $1200-1600 \mathrm{~m}$ just below the ELA. Figure $8 \mathrm{~b}$ shows that, near and below the ELA, melt dominates the change in runoff. In the highest area, above the ELA, refreezing is capable of balancing the melt and thereby eliminating changes in runoff.

\section{Discussion}

\section{a. HIRHAM5 versus observations and other models}

At the lowest PROMICE sites, NUK_L and NUK_N, model albedo is overestimated by about 0.1 . With a typical AMJJAS-mean downwelling SW flux of $200 \mathrm{~W} \mathrm{~m}^{-2}$, the 0.1 overestimate in albedo alone leads to an underestimated energy input of some $20 \mathrm{~W} \mathrm{~m}^{-2}$ to the surface energy budget at these low-elevation sites. Combined with biases in downwelling LW $\left(-20\right.$ and $\left.-15 \mathrm{~W} \mathrm{~m}^{-2}\right)$ and $\mathrm{SW}\left(+20\right.$ and $\left.+5 \mathrm{~W} \mathrm{~m}^{-2}\right)$, this results in radiative biases of about $-25 \mathrm{~W} \mathrm{~m}^{-2}$ (excluding biases in upwelling LW due to surface temperature biases). A constant deficit of $25 \mathrm{~W} \mathrm{~m}^{-2}$ corresponds to $1.2 \mathrm{~m}$ w.eq. of melting over 6 months, a conservative estimate since it neglects the correlation between albedo and insolation, producing extra
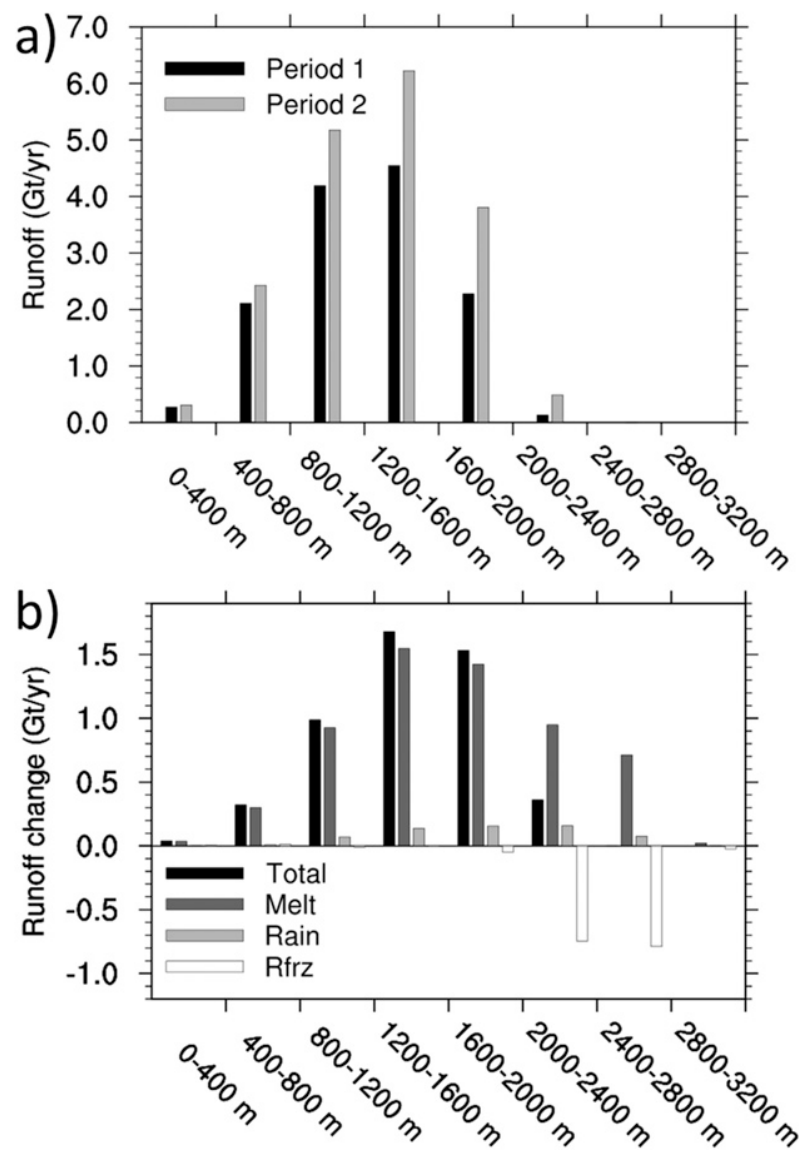

FIG. 8. (a) Total simulated annual runoff summed over surfaceelevation intervals on the ice sheet in the two periods. (b) Black bars show differences between the period 1 and period 2 runoffs in (a). These total changes are further decomposed into contributions from changes in melt, rain, and refreezing. Note that the elevation intervals do not cover equal surface areas because of the hypsometry of the ice sheet.

high melt at the peak of the ablation season. It is less than but approaching the roughly $2 \mathrm{~m}$ w.eq. of summer ablation that HIRHAM5 is missing compared to the NUK_L and NUK_N observations (Fig. 3a). At NUK_U (1140m), the HIRHAM5 deficit in ablation is only about $0.7 \mathrm{~m}$ w.eq. so the error is likely dominated by the area below $1000 \mathrm{~m}$. A missing annual melt of $2 \mathrm{~m}$ w.eq. in the entire area below $1000 \mathrm{~m}$ elevation $\left(1630 \mathrm{~km}^{2}\right)$ corresponds to about $3 \mathrm{Gt} \mathrm{yr}^{-1}$ of extra runoff: that is, $20 \%$ of the total annual model runoff.

The fact that the period 2 MODIS-derived ELA generally is lower than the simulated ELA (Fig. 6b) indicates that simulated SMB is underestimated at elevations near the ELA, that the MODIS-derived ELA is underestimated, or both. The former would imply a compensation at these higher elevations for the underestimated melt at low elevations. This parallels the conclusions for RACMO2 and MARv3.2 by van As 
TABLE 2. Annual averages ( \pm std dev) over the period 1991-2012 integrated over the entire Godthåbsfjord drainage basin of the ice sheet in HIRHAM5 (this study) compared to RACMO2 and MARv3.2 (data from van As et al. 2014). Also displayed are the period 1 to 2 changes.

\begin{tabular}{|c|c|c|c|c|c|c|}
\hline \multirow[b]{3}{*}{$\operatorname{Mass}\left(\mathrm{Gt} \mathrm{yr}^{-1}\right)$} & \multicolumn{3}{|c|}{ Total } & \multicolumn{3}{|c|}{ Change } \\
\hline & \multicolumn{3}{|c|}{ 1991-2012 } & \multicolumn{3}{|c|}{ Period $2-$ period 1} \\
\hline & HIRHAM5 & RACMO2 & MARv3.2 & HIRHAM5 & RACMO2 & MARv3.2 \\
\hline SMB & $4.1 \pm 6.2$ & $11.7 \pm 7.3$ & $6.3 \pm 7.0$ & -6.3 & -6.3 & -7.8 \\
\hline Solid accumulation & $17.3 \pm 3.4$ & $23.0 \pm 4.5$ & $21.4 \pm 2.7$ & -2.0 & -1.3 & -1.4 \\
\hline Melt & $23.4 \pm 6.9$ & $27.0 \pm 8.0$ & $27.7 \pm 8.4$ & 5.9 & 7.6 & 8.4 \\
\hline Refreezing & $10.2 \pm 2.7$ & $15.7 \pm 4.2$ & $12.7 \pm 2.7$ & 1.6 & 2.5 & 1.9 \\
\hline Rain & $2.8 \pm 1.4$ & $3.3 \pm 1.5$ & $2.7 \pm 1.1$ & 0.6 & 0.6 & 0.5 \\
\hline Snowfall & $18.6 \pm 3.4$ & $25.2 \pm 4.5$ & $21.2 \pm 2.6$ & -2.1 & -1.4 & -1.5 \\
\hline Runoff & $16.0 \pm 5.3$ & $14.5 \pm 5.5$ & $16.8 \pm 6.5$ & 4.9 & 5.6 & 6.9 \\
\hline
\end{tabular}

et al. (2014) and is in line with the mere $10 \%$ underestimate in Tasersuaq Lake runoff.

Table 2 compares HIRHAM5 1991-2012 averages of the Godthåbsfjord drainage basin totals to numbers from the RACMO2 and MARv3.2 simulations by van As et al. (2014) (similarly forced by ERA-Interim in this period). Our melt of $23.4 \pm 6.9 \mathrm{Gt} \mathrm{yr}^{-1}$ is $13 \%$ and $16 \%$ lower than RACMO2 $(27.0 \pm 8.0)$ and MARv3.2 $(27.7 \pm 8.4)$, respectively. These models also underestimate downwelling longwave and overestimate surface albedo, leading to $30 \%-50 \%$ underestimates in ablation at NUK_L (van As et al. 2014). It is unclear which combination of parameters causes the HIRHAM5 total melt to be about $4 \mathrm{Gt} \mathrm{yr}^{-1}$ lower and at which elevation. Refreezing $\left(10.2 \pm 2.7 \mathrm{Gt} \mathrm{yr}^{-1}\right)$ is also lower in HIRHAM5 (35\% and 20\% lower than $15.7 \pm 4.2 \mathrm{Gt} \mathrm{yr}^{-1}$ and $12.7 \pm 2.7 \mathrm{Gt} \mathrm{yr}^{-1}$ in RACMO2 and MARv3.2), resulting in similar runoff in all three models (within $10 \%$ on average). By far the largest difference between HIRHAM5 and the other models is found in precipitation, presumably related to the higher spatial resolution used. Even though the comparison with measurements suggests that HIRHAM5 overestimates precipitation in the coastal area of the domain, the large interior of the ice sheet must be the dominant factor in this difference.

The resulting 1991-2012 HIRHAM5 SMB for the Godthåbsfjord drainage basin of $4.1 \pm 6.2 \mathrm{Gt} \mathrm{yr}^{-1}$ is $65 \%$ lower than the corresponding mean value in RACMO2 $\left(11.7 \pm 7.3 \mathrm{Gt} \mathrm{yr}^{-1}\right)$ and $35 \%$ lower than in MARv3.2 (6.3 $\left.\pm 7.0 \mathrm{Gt} \mathrm{yr}^{-1}\right)$. In fact, an extra $3 \mathrm{Gt} \mathrm{yr}^{-1}$ runoff from the area below $1000 \mathrm{~m}$, as speculated before, brings the HIRHAM5 SMB even further down to $\sim 1 \mathrm{Gt} \mathrm{yr}^{-1}$. As discussed by van As et al. (2014), however, considerations of SMB versus estimated frontal ablation and ice sheet surface height changes indicate that RACMO2 and MARv3.2 SMBs are overestimated. When adjusted downward as proposed by van As et al. the 1991-2012 SMB of these models is in the $1-4 \mathrm{Gt} \mathrm{yr}^{-1}$ range. Whether this agreement with HIRHAM5 is coincidence is difficult to assess from the point observations, but the three models have very similar runoff [which we argue based on low-elevation melt underestimation and the findings of van As et al. (2014) should be increased by $3 \mathrm{Gt} \mathrm{yr}^{-1}$ ] in the period 1991-2012 (Table 2). Given the agreement between modeled and ice core-derived accumulation found by Lucas-Picher et al. (2012), it is possible that the high resolution in HIRHAM5 compared to the other models produces a more realistic accumulation field in the large ice sheet interior despite the apparent overestimation of orographic precipitation near the margin. If this is the case, the downward adjustment of RACMO2 and MARv3.2 SMBs arrived at by van As et al. (2014) is due in roughly equal parts to an increase in runoff and a decrease in precipitation.

\section{b. Changes over the simulation period}

The only significant mass changes between periods 1 and 2 occur for melt, runoff and SMB (Table 1). Changes in solid accumulation, rain, and refreezing are too small compared to interannual variability to be significant and the increase in melt generally controls the runoff and SMB in this simulation. A $6.3 \mathrm{Gt} \mathrm{yr}^{-1}$ decrease of SMB in the study area comes about as the sum of 2.7 and $3.2 \mathrm{Gt} \mathrm{yr}^{-1}$ extra melt in the former ablation and accumulation zones, respectively, and opposing (insignificant) effects of $1.5 \mathrm{Gt} \mathrm{yr}^{-1}$ from decreased solid accumulation and extra refreezing in the accumulation zone. For comparison (see Table 2), the RACMO2 and MARv3.2 SMB decreases between periods 1 and 2 are 6.3 and $7.8 \mathrm{Gt} \mathrm{yr}^{-1}$ (van As et al. 2014). These changes are similar; as are the SMB component changes. This indicates that, in spite of an offset between the models in melt and accumulation (because of resolution; parameterization schemes; or, most likely, both), there is a general agreement on the changes in SMB and its components. 
In HIRHAM5, the melt increase is due to significant increases in net SW and turbulent fluxes. In the ablation zone, upward LW flux does not balance the increase in energy input since the summer surface is already at or near freezing. Moreover, practically all the extra melt is permitted to run off since the shallow ablation zone snow layer has insufficient cold content to refreeze it. In the much larger accumulation zone, upward LW fluxes more efficiently balance the extra energy input and the per-area melt change is less than $20 \%$ of that in the ablation zone.

Simulated increases in net SW and turbulent heat fluxes are due to a general decrease in cloud cover and increase in horizontal atmospheric heat advection. Figure 9 illustrates that, between periods 1 and 2, the entire western part of Greenland experienced a reduction in total cloud cover (colors). This increases downwelling SW radiation and, as temperature increases and bare ice becomes more widespread, the melt-albedo feedback amplifies the net SW increase. The changes in lower tropospheric pressure patterns are illustrated by the $850-\mathrm{hPa}$ height contours. This change leads to more frequent southerly winds in the area, warm advection and increased downward sensible heat flux.

This has led to a decrease in SMB and an upward migration of the ELA, the details of which are possible to resolve in HIRHAM 5 at $5.5 \mathrm{~km}$. The correlation between annual SMB and ELA (with a slope of about $4 \mathrm{Gt} \mathrm{yr}^{-1}$ SMB per $100 \mathrm{~m}$ ELA; Fig. 5b) and the statistically indistinguishable slopes of the model- and MODIS-derived ELAs in Fig. 5b give further confidence in the magnitude of the SMB change. Combined with the similarity of the three models' changes in SMB and its components (Table 2), this gives us confidence that, in terms of the changes, we are close to the right numbers for the right reasons.

Turning to the year-to-year variability in Fig. 5 , the summers of 2007 and 2010 set new record minima for simulated SMB in the study area. All three components of the SMB are important for determining whether a large melt year sets record SMB: 2007 has the second-largest melt in the simulation but accumulation is near average and refreezing rather high; 2012 has by far the largest melt but is compensated by higher accumulation and refreezing; and 2010 was special because large melt was combined with the lowest accumulation over the simulation period (also reducing refreezing). The dashed gray curve in Fig. 5a illustrates how the simulated refreezing is well approximated by the least squares fit $0.38 \times($ melt + rain) with a correlation of 0.96 . There are years where the two curves diverge, however, and 2010 is one such

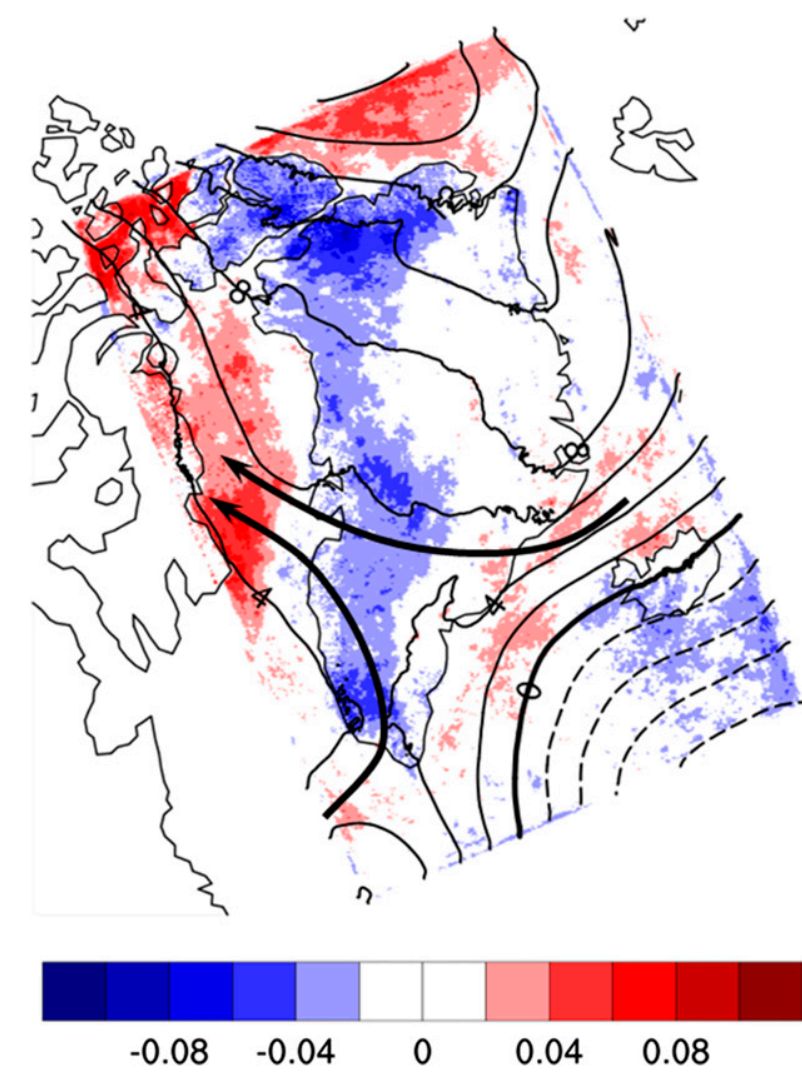

FIG. 9. Difference in simulated total cloud cover (shading; unitless) and 850-hPa geopotential height (contours; interval of $2 \mathrm{~m}$ ), period 2 - period 1 . The black arrows indicate schematically the direction of anomalous geostrophic winds associated with the 850-hPa height change.

year. The years 2009 and 2010 (along with 2011) have low solid accumulation at all surface-elevation intervals (Fig. 4). This means that the snowpack in the summer of 2010 was thinner and provided reduced refreezing capacity. In addition, the extra melt in 2010 occurred chiefly in the lower and middle intervals (mainly because of large turbulent fluxes; Fig. 4), where the snowpack generally has less cold content. The result is that 2010 had a particularly low refreezing fraction and, combined with high melt and low accumulation, the SMB was at minimum.

\section{c. Longer-term perspective}

To put these findings into a perspective longer than the simulated $22 \mathrm{yr}$, we compare the overall development in the Godthåbsfjord drainage basin of the ice sheet to the Nuuk Danish Meteorological Institute (Nuuk-DMI) meteorological station (Cappelen 2013). Because of possible inhomogeneity in the precipitation record prior to about 1952, we primarily focus on the period 1952-2012. Figure 10a shows the observed JJA 2-m temperature for 1890-2012 (black) compared to the annual total 


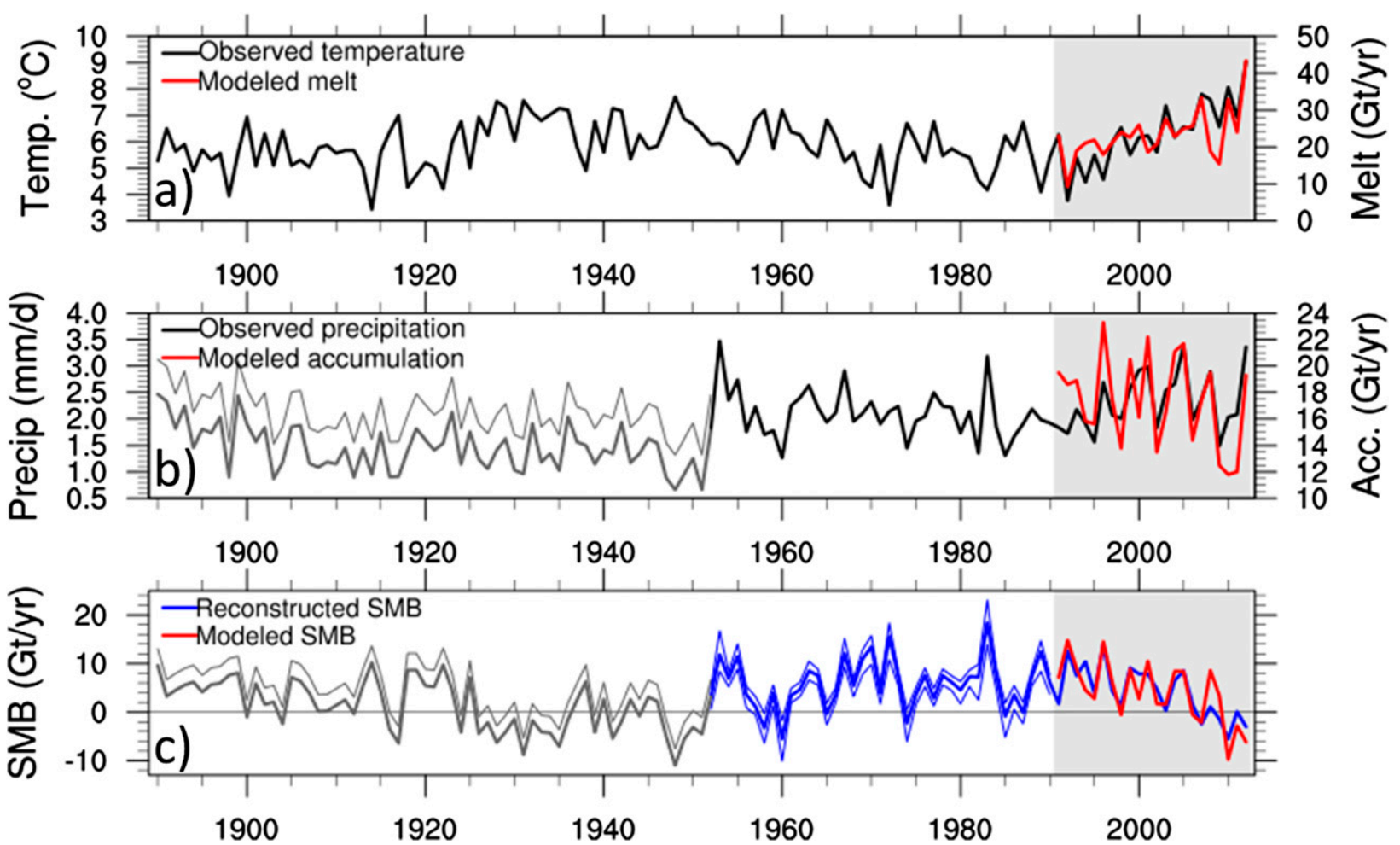

FIG. 10. (a) Observed JJA temperatures at the Nuuk-DMI station 1890-2012 (black; left axis) and simulated total annual ice sheet melt in the Godthåbsfjord drainage basin (red; right axis). (b) Observed annual average precipitation at Nuuk-DMI (black and gray; left axis) and simulated total annual solid accumulation in the drainage (red; right axis). (c) Reconstruction of SMB in the drainage (blue and gray) based on multivariate linear regression of modeled SMB (red) onto observed temperature and precipitation. Thin blue curves indicate the $95 \%$ confidence envelope (see text). In (b),(c), the thick (thin) gray curves show the case without (with) adjusting the pre-1952 precipitation upward by $0.66 \mathrm{~mm} \mathrm{day}^{-1}$.

simulated melt in the drainage basin (1991-2012; red). In addition to the upward trend, the two curves show several similar features during the overlapping period. Figure $10 \mathrm{~b}$ shows the observed annual-mean precipitation rate at Nuuk-DMI (black and gray). The thick gray is the raw published precipitation in the period 1890-1951, and there appears to be a shift in the record between the periods before and after 1952. According to Cappelen (2013), it is unclear whether this is an inhomogeneity in the record or if it, in fact, is a real climate signal as interpreted by Mernild et al. (2015). We cautiously mark the pre-1952 part of the record in gray and include an alternative (thin gray) through shifting it upward by $0.66 \mathrm{~mm} \mathrm{day}^{-1}$, giving equal mean values before and after 1952. Figure 10b also shows total simulated solid accumulation in the drainage basin (red). The similarities seen in Fig. 10a (between observed temperature and modeled melt) and Fig. 10b (between observed precipitation and modeled accumulation), combined with the high correlation of refreezing with melt plus rainfall seen in Fig. 5a, justifies a regression of the simulated SMB onto the two Nuuk-DMI series.
The result is shown in Fig. 10c (thick blue) and compared with the simulated SMB (red). The partial regression coefficients for Nuuk-DMI JJA temperature and annual-mean precipitation are $-4.6\left(\mathrm{Gt} \mathrm{yr}^{-1}\right) \mathrm{K}^{-1}$ and $5.2\left(\mathrm{Gt} \mathrm{yr}^{-1}\right)\left(\mathrm{mm} \mathrm{day}^{-1}\right)^{-1}$, respectively. This means that, for every warming of $1 \mathrm{~K}$ at Nuuk-DMI, the SMB decreases by $4.6 \mathrm{Gtyr}^{-1}$. For every $1 \mathrm{~mm}$ day $^{-1}$ increase in annual-mean precipitation at Nuuk-DMI, the SMB increases by $5.2 \mathrm{Gt} \mathrm{yr}^{-1}$. Such fluctuations routinely occur in the record, and the standardized partial regression coefficients are -0.90 and 0.46 for temperature and precipitation, respectively. This means that, in the overlapping period, a one standard deviation change in Nuuk temperature leads to a -0.90 standard deviation change in SMB (and 0.46 for precipitation). Temperature changes are thus roughly twice as important for SMB as precipitation in the simulation period. Much of the temperature variance in the simulation period is due to the upward trend. If the series are detrended before performing the regression, the partial regression coefficients do not change much (which are desirable, because this means that our regression does not rely on the trend) but the standardized coefficients 
become -0.60 and 0.56. Excluding the trend in temperature, precipitation fluctuations are thus as important as temperature fluctuations.

The trend in temperature and the response in SMB provide valuable information, however, so the series is not detrended when making the reconstruction of SMB shown by the blue curve in Fig. 10c. The thin blue curves mark the $95 \%$ confidence interval, which is estimated through a bootstrap procedure: the blue curve is based on a regression over $22 \mathrm{yr}$, and we thus pick 22 years out of the 1991-2012 series at random with replacement. This new 22-yr sample is then used to derive a new set of regression coefficients. This procedure is repeated 10000 times and gives a band of reconstructions reflecting the uncertainty in the regression. In each year, the thin blue curves mark the 2.5th and 97.5th percentiles of this band. Prior to 1952, we show in thick and thin gray curves the result of reconstructing using the raw and shifted precipitation curves, respectively.

The reconstruction suggests that low SMBs similar to those seen in the last few years have occurred earlier in the past $61 \mathrm{yr}$. This is in line with the findings by van As et al. (2014): around 1960, SMBs were close to zero for the Godthåbsfjord drainage basin. Prior to 1952, extended periods of low SMB appear to have occurred, whether we consider the raw or shifted precipitation data. In line with what was found by Box (2013) in a reconstruction of all-Greenland SMB, the time around 1930 was especially one of prolonged low SMB as a result of high melt and low accumulation.

\section{Conclusions}

The HIRHAM5 regional climate model has been run over an all-Greenland domain at $0.05^{\circ}$ resolution over the period 1991-2012. The experiment is forced by ERA-Interim data at the lateral boundaries and sea surface temperatures and sea ice in ocean points within the domain. While daily and interannual variability of near-surface air temperature and downwelling SW and LW fluxes at observation sites is well represented in the model, there are biases, most notably in orographic precipitation and ice sheet surface albedo. At the low elevations, model albedo was about 0.1 too high during the melt season. Combined with biases in downwelling LW and SW fluxes, this gives a deficit in melt energy, which is responsible for most of the roughly $2 \mathrm{~m}$ w.eq. of summer ablation that HIRHAM5 is missing compared to ablation observations. An additional $2 \mathrm{~m}$ w.eq. ablation in the area below $1000 \mathrm{~m}$ corresponds to an extra runoff of $3 \mathrm{Gt} \mathrm{yr}^{-1}$.
The modeled 1991-2012 SMB for the Godthåbsfjord drainage is about $4 \mathrm{Gt} \mathrm{yr}^{-1}$ and the additional $3 \mathrm{Gt} \mathrm{yr}^{-1}$ of runoff shifts the estimated SMB down to $\sim 1 \mathrm{Gt} \mathrm{yr}^{-1}$. This is considerably lower than the values computed with the RACMO2 and MARv3.2 RCMs presented by van As et al. (2014). However, comparing SMB versus estimated frontal ablation and ice sheet surface height changes, van As et al. concluded that the SMBs in those models are overestimated. Adjusted accordingly, their 1991-2012 SMBs lie in the 1-4 Gt yr ${ }^{-1}$ range, in line with our adjusted estimate. Given that RACMO2, MARv3.2, and HIRHAM5 have similar unadjusted runoffs (Table 2) and that they underestimate low-elevation summer ablation by comparable amounts (van As et al. 2014), the runoff is about $18-20 \mathrm{Gt} \mathrm{yr}^{-1}$. With this magnitude of runoff, the accumulation in RACMO2 in particular is too high

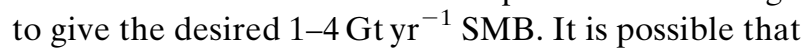
the high resolution in HIRHAM5 compared to the other models produces a more realistic accumulation field in the large ice sheet interior, despite an apparent overestimation of orographic precipitation near the margin.

In spite of differences in the mean between the models over the period 1991-2012, the changes over the period in SMBs and its components are quite similar in the three models (Table 2). In combination with the fidelity of the HIRHAM5 simulation in terms of synoptic and interannual variability and the decadal change in ELA compared to MODIS observations, this gives confidence in the mechanisms and tendencies presented here and encourages further studies on a Greenland-wide scale with this model configuration.

Melt rates have increased in the last decade because of increased downward sensible heat flux at low to middle elevations and increased net shortwave radiation at all elevations. These changes are related to changes in atmospheric horizontal heat advection and cloudiness combined with ensuing surface albedo changes. In spite of general warming in the region, these changes cannot directly be attributed to anthropogenic warming because of underlying interannual and interdecadal variability in the atmospheric circulation. The dependence on circulation changes means that it would be wrong to simply scale up the numbers found here to give Greenland-wide values (the study area covers $2.6 \%$ of the entire ice sheet), since the western part of Greenland seems to be particularly prone to melting during negative NAO years (Fettweis et al. 2013b) and blocking events (Hanna et al. 2014).

Because of the simulated increase in melt rates (5.9 $\mathrm{Gt} \mathrm{yr}^{-1}$ between the periods 1991-2001 and 200212 for the entire Godthåbsfjord drainage basin), the 
SMB has declined $\left(-6.3 \mathrm{Gt} \mathrm{yr}^{-1}\right)$, the runoff has increased $\left(4.9 \mathrm{Gtyr}^{-1}\right)$, and the ELA has increased (about 140 m). Over the experiment period 1991-2012, we regressed SMB onto observed summer temperatures and annual precipitation at the Nuuk-DMI station allowing us to estimate the SMB back to 1952, with an extension back to 1890 with some uncertainty due to possible inhomogeneity in the precipitation record. SMBs as low as those in recent years appear to be rare but have occurred before, most notably around 1930, 1950, and 1960. An important difference is that, while previous low SMBs were mainly or partially due to low accumulation, those around 1930 and in the 2000s are driven mainly by the warming.

Simulated liquid freshwater input to Godthåbsfjord (excluding solid ice discharge and basal and submarine melt) averages $25.0 \pm 5.9 \mathrm{Gt} \mathrm{yr}^{-1}$. Of this, about $64 \%$ derives from ice sheet runoff, $31 \%$ derives from land runoff and $5 \%$ derives from precipitation minus evaporation over the fjord surface. In addition to this, the frontal ablation contributes with an estimated input of roughly 7-10 $\mathrm{Gt} \mathrm{yr}^{-1}$ (van As et al. 2014, and references therein). The total ice sheet contribution thus dominates the freshwater input to the fjord. Of the simulated freshwater contributions to the fjord, only that from the ice sheet was found to change significantly (by $4.9 \mathrm{Gtyr}^{-1}$, compared to 5.6 and 6.9 $\mathrm{Gt} \mathrm{yr}^{-1}$ in RACMO2 and MARv3.2). This means that, when studying changes in the fjord freshwater balance, the contributions from land and sea points may be neglected.

Acknowledgments. The authors wish to thank three anonymous reviewers for thorough and helpful comments on the manuscript. We also thank Jason E. Box for assisting with the MODIS-derived ELA estimates used in the study along with London Mining and GCNet (CIRES) for use of weather observations. The study received financial support from the Danish Agency for Science, Technology, and Innovation, the Danish Energy Agency, and is a part of Greenland Climate Research Centre activities. Funding was also provided from the Nordic Council of Ministers within the Top-Level Research Initiative (TRI) program Biogeochemistry in a Changing CryosphereDepicting Ecosystem-Climate Feedbacks as Affected by Changes in Permafrost, Snow and Ice Distribution (DEFROST), as well as PROMICE, FreshLink, and SVALI. The Nordic Centre of Excellence Stability and Variations of Arctic Land Ice (SVALI) is funded by the Nordic Top-Level Research Initiative (TRI).

\section{APPENDIX}

\section{Statistical Significance of Changes and Trends}

Changes between periods 1 and 2 that are statistically significant at the $95 \%$ level are marked in bold in Table 1. Further, section 4a discusses statistically significant trends in Fig. 4. This appendix describes how these significances are assessed.

Consider a series $X$ from which we cut out subsections $X_{1}$ and $X_{2}$, corresponding to the periods 1 and 2. The means of these subsections are denoted $m_{1}$ and $m_{2}$, and the statistical test is to reject with some confidence the null hypothesis that $m_{1}=m_{2}$. This is done using the two-tailed Student's $t$ test (von Storch and Zwiers 2001). In the calculation of the $t$ statistic, we need the means $m_{1}$ and $m_{2}$ and the variance of the series $v$, which is taken to be constant over the entire series. In assessing the probability of attaining a certain $t$ statistic by chance, we need the sample sizes $N_{1}$ and $N_{2}$.

A large trend will lead to a large variance in the series and the significance of the change will appear small. This is undesired and the series is therefore detrended prior to calculation of the variance. This isolates the variance unrelated to the underlying change whose significance we are assessing.

Care needs to be taken also when determining the sample sizes. Typically, geophysical time series have serial autocorrelations, which tend to decrease the effective degrees of freedom. This is treated by dividing the sample length by the autocorrelation time scale. As with the variance, the underlying trend influences the autocorrelation time scale and thereby decreases the degrees of freedom. Again, this is undesired so we use the autocorrelation of the detrended series. Most of the annual variables considered show no autocorrelation after this detrending.

When assessing the significance of linear trends in Fig. 4, a $t$ statistic is calculated on the regression coefficient. This $t$ statistic is then used to reject with some confidence the null hypothesis that the regression coefficient is zero. In determining this confidence, the sample size is needed, and serial correlations again need to be considered. We do this by calculating the residual between the original series and the linear regression. The autocorrelation of this residual series is then used to adjust the sample size.

\section{REFERENCES}

Aðalgeirsdóttir, G., A. Aschwanden, C. Khroulev, F. Boberg, R. Mottram, P. Lucas-Picher, and J. H. Christensen, 2014: Role 
of model initialisation for projections of 21st century Greenland Ice Sheet mass loss. J. Glaciol., 60, 782-794, doi:10.3189/ 2014JoG13J202.

Ahlstrøm, A. P., and Coauthors, 2008: A new programme for monitoring the mass loss of the Greenland Ice Sheet. Geol. Surv. Den. Greenl. Bull., 15, 61-64.

Allerup, P., H. Madsen, and F. Vejen, 2000: Correction of observed precipitation in Greenland. Proc. 21st Nordic Hydrological Conf., Uppsala, Sweden, Nordic Association for Hydrology.

Andersen, K. K., P. D. Ditlevsen, S. O. Rasmussen, H. B. Clausen, B. M. Vinther, S. J. Johnsen, and J. P. Steffensen, 2006: Retrieving a common accumulation record from Greenland ice cores for the past 1800 years. J. Geophys. Res., 111, D15106, doi:10.1029/2005JD006765.

Aschwanden, A., G. Aðalgeirsdóttir, and C. Khroulev, 2013: Hindcasting to measure ice sheet model sensitivity to initial states. Cryosphere, 7, 1083-1093, doi:10.5194/tc-7-1083-2013.

Bales, R. C., and Coauthors, 2009: Annual accumulation for Greenland updated using ice core data developed during 2000-2006 and analysis of daily coastal meteorological data. J. Geophys. Res., 114, D06116, doi:10.1029/2008JD011208.

Bamber, J. L., S. Ekholm, and W. B. Krabill, 2001: A new, highresolution digital elevation model of Greenland fully validated with airborne laser altimeter data. J. Geophys. Res., 106, 6733 6745, doi:10.1029/2000JB900365.

Banta, J. R., and J. R. McConnell, 2007: Annual accumulation over recent centuries at four sites in central Greenland. J. Geophys. Res., 112, D10114, doi:10.1029/2006JD007887.

Barletta, V. R., L. S. Sørensen, and R. Forsberg, 2013: Scatter of mass changes estimates at basin scale for Greenland and Antarctica Cryosphere, 7, 1411-1432, doi:10.5194/tc-7-1411-2013.

Benson, R., and J. Box, 2008: MODIS-derived Greenland Ice Sheet equilibrium line altitude 2000-2008: Comparison with surface melt and accumulation variability. Eos, Trans. Amer. Geophys. Union, 89 (Fall Meeting Suppl.), Abstract C31E-0570.

Box, J. E., 2013: Greenland Ice Sheet mass balance reconstruction. Part II: Surface mass balance (1840-2010). J. Climate, 26, 6974-6989, doi:10.1175/JCLI-D-12-00518.1.

_ , and A. Rinke, 2003: Representation of Greenland Ice Sheet surface climate in the HIRHAM regional climate model. J. Climate, 16, 1302-1319, doi:10.1175/1520-0442-16.9.1302.

—, X. Fettweis, J. C. Stroeve, M. Tedesco, D. K. Hall, and K. Steffen, 2012: Greenland ice sheet albedo feedback: Thermodynamics and atmospheric drivers. Cryosphere, 6, 821-839, doi:10.5194/tc-6-821-2012.

Cappelen, J., Ed., 2013: Weather observations from Greenland 19582012-Observation data with description. Danish Meteorological Institute Tech. Rep. 13-11, 23 pp. [Available online at http:// www.dmi.dk/fileadmin/Rapporter/TR/tr13-11.pdf.]

Christensen, J. H., and Coauthors, 2014: Climate phenomena and their relevance for future regional climate change. Climate Change 2013: The Physical Science Basis, T. F. Stocker et al., Eds., Cambridge University Press, 1217-1308.

Christensen, O. B., M. Drews, J. H. Christensen, K. Dethloff, K. Ketelsen, I. Hebestadt, and A. Rinke, 2006: The HIRHAM regional climate model, version 5. Danish Meteorological Institute Tech. Rep. 06-17, 22 pp. [Available online at http:// www.dmi.dk/fileadmin/Rapporter/TR/tr06-17.pdf.]

Church, J. A., and Coauthors, 2014: Sea level change. Climate Change 2013: The Physical Science Basis, T. F. Stocker et al., Eds., Cambridge University Press, 1137-1216.
Coléou, C., and B. Lesaffre, 1998: Irreducible water saturation in snow: Experimental results in a cold laboratory. Ann. Glaciol., 26, 64-68.

Cuffey, K. M., and W. S. B. Paterson, 2010: The Physics of Glaciers. 4th ed. Elsevier, 708 pp.

Daanen, R., P. Ingeman-Nielsen, S. S. Marchenko, V. E. Romanovsky, N. Foged, M. Stendel, J. H. Christensen, and K. H. Svensen, 2011: Permafrost degradation risk zone assessment using simulation models. Cryosphere, 5, 1043-1056, doi:10.5194/ tc-5-1043-2011.

Dee, D. P., and Coauthors, 2011: The ERA-Interim reanalysis: Configuration and performance of the data assimilation system. Quart. J. Roy. Meteor. Soc., 137, 553-597, doi:10.1002/qj.828.

Eerola, K., 2006: About the performance of HIRLAM version 7.0. HIRLAM Newsletter, No. 51, HIRLAM-A Pogramme, De Bilt, Netherlands, 93-102.

Ettema, J., M. R. van den Broeke, E. van Meijgaard, W. J. van de Berg, J. L. Bamber, J. E. Box, and R. C. Bales, 2009: Higher surface mass balance of the Greenland ice sheet revealed by high-resolution climate modeling. Geophys. Res. Lett., 36, L12501, doi:10.1029/2009GL038110.

Fausto, R. S., D. van As, A. P. Ahlstrøm, and M. Citterio, 2012: Assessing the accuracy of Greenland Ice Sheet ice ablation measurements by pressure transducer. J. Glaciol., 58, 11441150, doi:10.3189/2012JoG12J075.

Fettweis, X., 2007: Reconstruction of the 1979-2006 Greenland Ice Sheet surface mass balance using the regional climate model MAR. Cryosphere, 1, 21-40, doi:10.5194/tc-1-21-2007.

— B. Branco, M. Tedesco, J. H. van Angelen, J. T. M. Lenaerts, M. R. van den Broeke, and H. Gallee, 2013a: Estimating the Greenland ice sheet surface mass balance contribution to future sea level rise using the regional atmospheric climate model MAR. Cryosphere, 7, 469-489, doi:10.5194/tc-7-469-2013.

- E. Hanna, C. Lang, A. Belleflamme, M. Erpicum, and H. Gallee, 2013b: Important role of the midtropospheric atmospheric circulation in the recent surface melt increase over the Greenland ice sheet. Cryosphere, 7, 241-248, doi:10.5194/ tc-7-241-2013.

Gillet-Chaulet, F., and Coauthors, 2012: Greenland ice sheet contribution to sea-level rise from a new-generation ice-sheet model. Cryosphere, 6, 1561-1576, doi:10.5194/tc-6-1561-2012.

Goelzer, H., and Coauthors, 2013: Sensitivity of Greenland Ice Sheet projections to model formulations. J. Glaciol., 59, 733749, doi:10.3189/2013JoG12J182.

Häkkinen, S., D. K. Hall, C. A. Shuman, D. L. Worthen, and N. E. DiGirolamo, 2014: Greenland Ice Sheet melt from MODIS and associated atmospheric variability. Geophys. Res. Lett., 41, 1600-1607, doi:10.1002/2013GL059185.

Hanna, E., and Coauthors, 2014: Atmospheric and oceanic climate forcing of the exceptional Greenland Ice Sheet surface melt in summer 2012. Int. J. Climatol., 34, 1022-1037, doi:10.1002/ joc.3743.

Herrera, S., L. Fita, J. Fernández, and J. M. Gutiérrez, 2010: Evaluation of the mean and extreme precipitation regimes from the ENSEMBLES regional climate multimodel simulations over Spain. J. Geophys. Res., 115, D21117, doi:10.1029/ 2010JD013936.

Howat, I. M., A. Negrete, and B. E. Smith, 2014: The Greenland Ice Mapping Project (GIMP) land classification and surface elevation data sets. Cryosphere, 8, 1509-1518, doi:10.5194/ tc-8-1509-2014

Humphrey, N. F., J. T. Harper, and W. T. Pfeffer, 2012: Thermal tracking of meltwater retention in Greenland's accumulation 
area. J. Geophys. Res., 117, F01010, doi:10.1029/ 2011JF002083.

Hvidegaard, S. M., L. S. Sørensen, and R. Forsberg, 2012: ASTER GDEM validation using LiDAR data over coastal regions of Greenland. Remote Sens. Lett., 3, 85-91, doi:10.1080/ 01431161.2010.527389.

International Organization for Standardization, 1998: Measurement of liquid flow in open channels-Part 2: Determination of the stage-discharge relation. International Organization for Standardization Standards Catalogue, 2nd ed., ISO 1100-2.

Iversen, K. M., and K. Thorsøe, 2009: ClimateBasic manual for NERO. Asiaq Rep. 2009-22, 15 pp.

Joughin, I., B. E. Smith, I. M. Howat, T. Scambos, and T. Moon, 2010: Greenland flow variability from ice-sheet-wide velocity mapping. J. Glaciol., 56, 415-430, doi:10.3189/ 002214310792447734.

Lucas-Picher, P., M. Wulff-Nielsen, J. H. Christensen, G. Aðalgeirsdóttir, R. Mottram, and S. Simonsen, 2012: Very high resolution in regional climate model simulations for Greenland: Identifying added value. J. Geophys. Res., 117, D02108, doi:10.1029/2011JD016267.

Mernild, S. H., and G. E. Liston, 2012: Greenland freshwater runoff. Part II: Distribution and trends, 1960-2010. J. Climate, 25, 6015-6035, doi:10.1175/JCLI-D-11-00592.1.

, - C C. A. Hiemstra, J. H. Christensen, M. Stendel, and B. Hasholt, 2011: Surface mass-balance and runoff modeling using HIRHAM4 RCM at Kangerlussuaq (Søndre Strømfjord), west Greenland, 1950-2080. J. Climate, 24, 609623, doi:10.1175/2010JCLI3560.1.

— , and Coauthors, 2015: Greenland precipitation trends in a long-term instrumental climate context (1890-2012): Evaluation of coastal and ice core records. Int. J. Climatol., 35, 303 320, doi:10.1002/joc.3986.

Mortensen, J., K. Lennert, J. Bendtsen, and S. Rysgaard, 2011: Heat sources for glacial melt in a sub-Arctic fjord (Godthåbsfjord) in contact with the Greenland Ice Sheet. J. Geophys. Res., 116, C01013, doi:10.1029/2010JC006528.

, J. Bendtsen, R. J. Motyka, K. Lennert, M. Truffer, M. Fahnestock, and S. Rysgaard, 2013: On the seasonal freshwater stratification in the proximity of fast-flowing tidewater outlet glaciers in a sub-Arctic sill fjord. J. Geophys. Res., 118, 1382-1395, doi:10.1002/jgrc. 20134.

,$- \ldots$, K. Lennert, and S. Rysgaard, 2014: Seasonal variability of the circulation system in a west Greenland tidewater outlet glacier fjord, Godthåbsfjord $\left(64^{\circ} \mathrm{N}\right)$. J. Geophys. Res. Earth Surf., 119, 2591-2603, doi:10.1002/2014JF003267.

Motyka, R. J., L. Hunter, K. A. Echelmeyer, and G. Connor, 2003: Submarine melting at the terminus of a temperate tidewater glacier, LeConte Glacier, Alaska, U.S.A. Ann. Glaciol., 36, 57-65, doi:10.3189/172756403781816374.

Nghiem, S. V., and Coauthors, 2012: The extreme melt across the Greenland ice sheet in 2012. Geophys. Res. Lett., 39, L20502, doi:10.1029/2012GL053611.

Oerlemans, J., and W. H. Knap, 1998: A 1 year record of global radiation and albedo in the ablation zone of Morteratschgletscher, Switzerland. J. Glaciol., 44, 231-238.

Rae, J. G. L., and Coauthors, 2012: Greenland Ice Sheet surface mass balance: Evaluating simulations and making projections with regional climate models. Cryosphere, 6, 1275-1294, doi:10.5194/tc-6-1275-2012.

Reijmer, C. H., M. R. van den Broeke, X. Fettweis, J. Ettema, and L. B. Stap, 2012: Refreezing on the Greenland ice sheet: A comparison of parameterizations. Cryosphere, 6, 743-762, doi:10.5194/tc-6-743-2012.

Rignot, E., M. Koppes, and I. Velicogna, 2010: Rapid submarine melting of the calving faces of West Greenland glaciers. Nat. Geosci., 3, 187-191, doi:10.1038/ngeo765.

- I. Velicogna, M. R. van den Broeke, A. Monaghan, and J. T. M. Lenaerts, 2011: Acceleration of the contribution of the Greenland and Antarctic Ice Sheets to sea level rise. Geophys. Res. Lett., 38, L05503, doi:10.1029/2011GL046583.

Rinke, A., H. Matthes, J. H. Christensen, P. Kuhry, V. E. Romanovsky, and K. Dethloff, 2012: Arctic RCM simulations of temperature and precipitation derived indices relevant to future frozen ground conditions. Global Planet. Change, 80-81, 136-148, doi:10.1016/j.gloplacha.2011.10.011.

Roeckner, E., and Coauthors, 2003: The atmospheric general circulation model ECHAM5. Part I: Model description. Max Planck Institute for Meteorology Rep. 349, 140 pp. [Available online at http://www.mpimet.mpg.de/fileadmin/publikationen/ Reports/max_scirep_349.pdf.]

Shepherd, A., and Coauthors, 2012: A reconciled estimate of icesheet mass balance. Science, 338, 1183-1189, doi:10.1126/ science.1228102.

Steffen, K., and J. E. Box, 2001: Surface climatology of the Greenland ice sheet: Greenland Climate Network 1995-1999. J. Geophys. Res., 106, 33 951-33 964, doi:10.1029/2001JD900161.

,-- , and W. Abdalati, 1996: Greenland climate network: GC-Net. Glaciers, ice sheets and volcanoes: A tribute to Mark F. Meier, S. C. Colbeck, Ed., CRREL Special Rep. $96-$ 27, 98-103.

Straneo, F., R. G. Curry, D. A. Sutherland, G. S. Hamilton, C. Cenedese, K. Våge, and L. A. Stearns, 2011: Impact of fjord dynamics and glacial runoff on the circulation near Helheim Glacier. Nat. Geosci., 4, 322-327, doi:10.1038/ngeo1109.

Tedesco, M., X. Fettweis, T. Mote, J. Wahr, P. Alexander, J. E. Box, and B. Wouters, 2013: Evidence and analysis of 2012 Greenland records from spaceborne observations, a regional climate model and reanalysis data. Cryosphere, 7, 615-630, doi:10.5194/tc-7-615-2013.

van Angelen, J. H., M. R. van den Broeke, B. Wouters, and J. T. M. Lenaerts, 2013: Contemporary (1960-2012) evolution of the climate and surface mass balance of the Greenland Ice Sheet. Surv. Geophys., 35, 1155-1174, doi:10.1007/s10712-013-9261-z.

van As, D., and Coauthors, 2013: Darkening of the Greenland Ice Sheet due to the melt-albedo feedback observed at PROMICE weather stations. Geol. Surv. Den. Greenl. Bull., 28, 69-72.

_ the Nuuk region of the Greenland Ice Sheet and implications for mass balance (1960-2012). J. Glaciol., 60, 314-322, doi:10.3189/2014JoG13J065.

van den Broeke, M. R., and Coauthors, 2009: Partitioning recent Greenland mass loss. Science, 326, 984-986, doi:10.1126/ science. 1178176 .

van de Wal, R. S. W., and J. Oerlemans, 1994: An energy balance model for the Greenland ice sheet. Global Planet. Change, 9, 115-131, doi:10.1016/0921-8181(94)90011-6.

_ W. Greuell, M. R. van den Broeke, C. H. Reijmer, and J. Oerlemans, 2005: Surface mass-balance observations and automatic weather station data along a transect near Kangerlussuaq, west Greenland. Ann. Glaciol., 42, 311-316, doi: $10.3189 / 172756405781812529$.

- W. Boot, C. J. P. P. Smeets, H. Snellen, M. R. van den Broeke, and J. Oerlemans, 2012: Twenty-one years of mass balance 
observations along the K-transect, west Greenland. Earth Syst. Sci. Data, 4, 31-35, doi:10.5194/essd-4-31-2012.

Vaughan, D. G., and Coauthors, 2014: Observations: Cryosphere. Climate Change 2013: The Physical Science Basis, T. F. Stocker et al., Eds., Cambridge University Press, 317-382.

Velicogna, I., 2009: Increasing rates of ice mass loss from the Greenland and Antarctic Ice Sheets revealed by GRACE. Geophys. Res. Lett., 36, L19503, doi:10.1029/ 2009GL040222.

, and J. Wahr, 2013: Time-variable gravity observations of ice sheet mass balance: Precision and limitations of the GRACE satellite data. Geophys. Res. Lett., 40, 3055-3063, doi:10.1002/ grl.50527.
Vernon, C. L., J. L. Bamber, J. E. Box, M. R. van den Broeke, X. Fettweis, E. Hanna, and P. Huybrechts, 2013: Surface mass balance model intercomparison for the Greenland Ice Sheet. Cryosphere, 7, 599-614, doi:10.5194/tc-7-599-2013.

von Storch, H., and F. W. Zwiers, 2001: Statistical Analysis in Climate Research. Cambridge University Press, 484 pp.

Wouters, B., D. Chambers, and E. J. O. Schrama, 2008: GRACE observes small-scale mass loss in Greenland. Geophys. Res. Lett., 35, L20501, doi:10.1029/2008GL034816.

Yang, D., S. Ishida, B. E. Goodison, and T. Gunther, 1999: Bias correction of daily precipitation measurements for Greenland. J. Geophys. Res., 104, 6171-6181, doi:10.1029/ 1998JD200110. 